
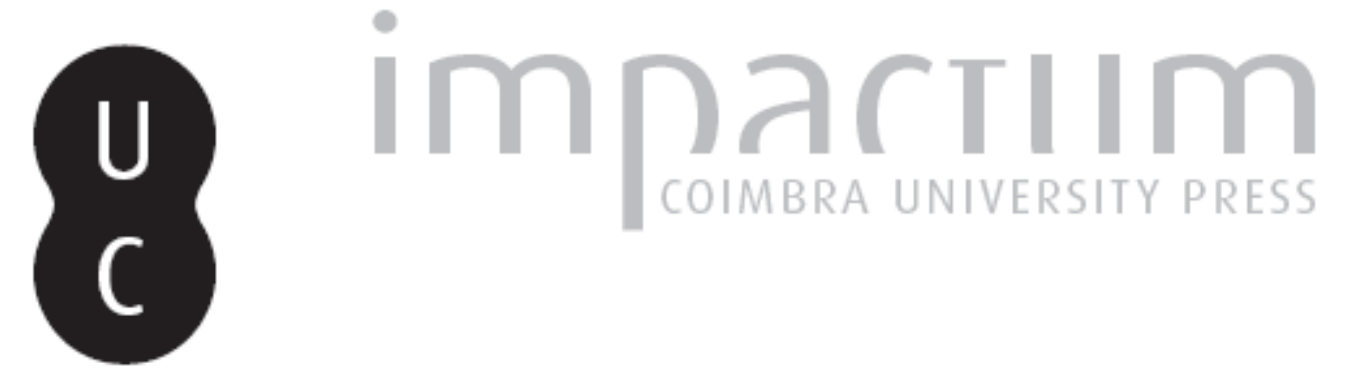

\title{
Considerações sobre a categoria gramatical de género: sua evolução do Latim ao Português Arcaico
}

\author{
Autor(es): $\quad$ Gouveia, Maria Carmen de Frias e \\ Publicado por: Faculdade de Letras da Universidade de Coimbra \\ URL \\ persistente: \\ URI:http://hdl.handle.net/10316.2/39985 \\ DOI: \\ DOI:https://doi.org/10.14195/0870-4112_2_17 \\ Accessed : $\quad$ 26-Apr-2023 13:26:08
}

A navegação consulta e descarregamento dos títulos inseridos nas Bibliotecas Digitais UC Digitalis, UC Pombalina e UC Impactum, pressupõem a aceitação plena e sem reservas dos Termos e Condições de Uso destas Bibliotecas Digitais, disponíveis em https://digitalis.uc.pt/pt-pt/termos.

Conforme exposto nos referidos Termos e Condições de Uso, o descarregamento de títulos de acesso restrito requer uma licença válida de autorização devendo o utilizador aceder ao(s) documento(s) a partir de um endereço de IP da instituição detentora da supramencionada licença.

Ao utilizador é apenas permitido o descarregamento para uso pessoal, pelo que o emprego do(s) título(s) descarregado(s) para outro fim, designadamente comercial, carece de autorização do respetivo autor ou editor da obra.

Na medida em que todas as obras da UC Digitalis se encontram protegidas pelo Código do Direito de Autor e Direitos Conexos e demais legislação aplicável, toda a cópia, parcial ou total, deste documento, nos casos em que é legalmente admitida, deverá conter ou fazer-se acompanhar por este aviso.

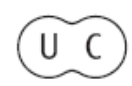


REVISTA DA FACULDADE DE LETRAS U N I VERS I A D E D E C O I M B RA 


\title{
DE GÉNERO.
}

Sua evoluçãodo Latimao Português Arcaico*

\begin{abstract}
:

This short essay deals with the grammatical gender in
nouns and adjectives, from an historical point of view, based on the
many glossaries, dictionaries and historical grammars.

$\begin{array}{lccccccccc} & \text { Departing } & \text { from the definition of what is in fact the grammatical } \\ \text { gender and what it is related to, this essay also refers to the evolution of this } \\ \text { morphological category from Indo-European to Latin, then to later Latin and from }\end{array}$
\end{abstract}
this variety to Portuguese.

The main point is the discussion of gender in the old Portuguese language. The analysis takes into account word-ending (words finishing in -or, ol, -nte, -es, -e, -ão), words coming from the ancient Latin neuter, word derivation and suffixation and gender, words with gender variation in the old language, the relation with semantics and morpho-phonological issues.

The conclusion refers to some chronological facts concerning gender evolution.

1. A categoria gramatical de género

O termo "género" provém do vocábulo latino "genus, -ëris", que tinha, nessa língua, para além de muitas outras acepções, o sentido de "classe" ou "tipo". Assim, os três géneros existentes em Latim e em Grego correspondiam às três principais classes em que os nomes se

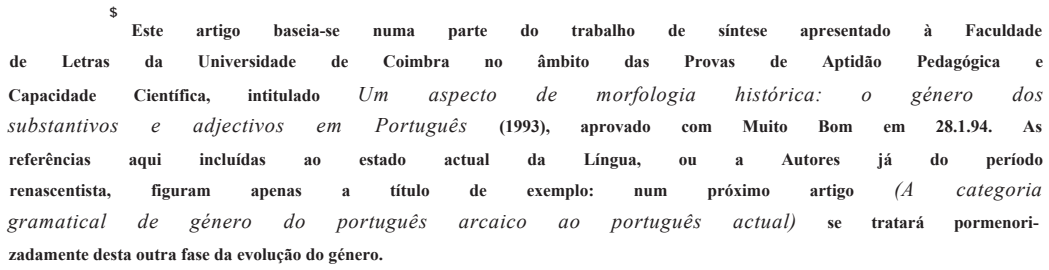




\section{Maria Carmen de Frias e Gouveia}

podiam dividir, isto é, masculino, feminino e neutro, que constituíam reflexos da relação vigente entre género e sexo ${ }^{1}$.Aliás, como nota W. Abraham $^{2}{ }^{*}$, na maioria das línguas que possuem o género como categoria gramatical pode encontrar-se uma certa base semântica "natural" para essa divisão, fruto da observação da vida real. Mas para entender o conceito de género é necessário distinguir género natural, que tem a ver com o sexo das entidades do mundo real, e género gramatical, que, para além da eventual correspondência com seres sexuados, desempenha um papel importante ao assinalar as relações de concordância entre as palavras de uma frase ${ }^{2}$.

Muitas pessoas, no entanto - e alguns gramáticos, o que é mais grave 4 -, persistem em "confundir" género e sexo, pelo que surgem inúmeras incongruências, ao tratar-se da categoria gramatical de género. Para compreendermos por que tal acontece, é útil abstrairmo-nos por um momento do campo estritamente linguístico e ter em conta factores de natureza social, religiosa e sexual ${ }^{5}$.

O factor social é extremamente importante na estruturação do léxico de uma língua. Da mesma forma que o género não é uma categoria universal (há línguas que a desconhecem), também nem todas as línguas deram a mesma relevância à diferença macho / fêmea (alguns idiomas baseiam o género em critérios de outra natureza, como sejam a forma ou a

* A divisão em masculino, feminino e neutro era baseada numa prévia repartição do Indo-europeu em género animado (que se viria a subdividir) e género inanimado (correspondente ao neutro). Por sua vez, o Latim seguia mais o critério formal que o natural (cf. M. Vilela, "Considerações gerais sobre o género" in Revista da Faculdade de Letras da Universidade do Porto, 1 (1973) 139-150), pois "pons" era masculino, "mensa", feminino e "animal", neutro, sendo o género usualmente explicitado pelo adjectivo.

W. Abraham, Diccionario de Terminología Lingüistica Actual (Madrid, Editorial Gredos 1981)214-215

2 D. Crystal, Dicionário de Lingüística e Fonética (Rio de Janeiro, Jorge Zahar Editor 1988) 124-125.

4 cf., entre outros, F. Brunot, Précis de grammaire historique de la langue française. (Paris, Masson et Cie. Éditeurs 1899) 229: «On appelle genre des noms la propriété qu'ils ont de distinguer par leur forme le sexe de l'étre ou de Fobjet qu'ils désignent» [itálico nosso]. Joaquim Mattoso Câmara Jr., em Estrutura da lingua portuguesa (Petrópolis, Rio de Janeiro, Ed. Vozes 1984) 88-89, afirma que «a flexão de gênero é exposta de uma maneira incoerente e confusa nas gramáticas tradicionais do português", ou mesmo que «as divisões das nossas gramáticas a respeito do que chamam inadequadamente "flexão de gênero" são inteiramente descabidas e perturbadoras da exata descrição gramatical».

5 M. Tereza Camargo Biderman, A categoria do gênero (São Paulo, FFLCH-USP $1974) 12$.

Faculdade de Letras I Universidade de Coimbra 


\section{Considerações sobre a categoria gramatical de género}

função dos objectos) $)^{6}$. Isto era já notorio em Latim, pois apenas os animais que faziam parte do quotidiano do povo latino tinham designações baseadas nessa distinção ${ }^{7}$, o que evoca a relação entre linguagem e conhecimento, de que vários autores já se ocuparam, como, por exemplo, Wittgenstein.

Também o factor religioso pode explicar alguns dos "problemas" ligados ao género. É curioso, a este propósito, lembrar alguns exemplos que estão relacionados com a tendência para, nos mitos, lendas ou personificações, criar representações antropomórficas para conceitos tais como a Aurora, a Noite, o Dia ou a Morte. Regra geral, identificaramse estas entidades com o sexo correspondente ao do género que a palavra tinha em Grego. Mas Dubois descreve uma outra situação: o Francês representa a Morte por uma mulher nas metáforas e alegorias, enquanto que em Inglês é um homem que a representa ${ }^{8}$.

Em Indo-europeu, como refere Lázaro Carretei*9, o género era natural, assentando numa oposição entre masculino e feminino. Afectava o substantivo, assinalando a distinção de sexos através de morfemas. A par deste género natural desenvolve-se outro, desta feita gramatical, que surge em designações de objectos (sem sexo, portanto) e ainda em adjectivos, pronomes e numerais, e que inclui também o neutro. A este respeito, é interessante notar que podem ainda ter género gramatical os nomes que designam seres vivos, podendo ser indiferente o género natural de um substantivo.

Assim, em suma, dentro do género natural são masculinos os nomes de seres do sexo masculino, femininos os de seres do sexo feminino e neutros os que podem, do ponto de vista sexual, considerar-se indiferentes ${ }^{10}$.

\footnotetext{
6 Para uma ideia sobre os vários sistemas de género do mundo, ver Greville G. Corbett, Gender (Cambridge, New York, Port Chester, Melbourne, Sydney, Cambridge University 1991).

7 Também em português se verifica a mesma situação: a par de designações desse tipo (gato / gata, boi / vaca, cavalo / égua, etc.), há unicamente uma para mosca, pulga ou formiga, ou ainda para elefante, rinoceronte, ou tigre, p. ex., por não haver necessidade de precisar o sexo: ou pelo seu reduzido tamanho, ou, sobretudo, por se encontrarem menos ligados ao quotidiano sócio-económico dos portugueses. cf. Muhammad Hasan Ibrahim, Grammatical Gender. Its Origin and Development (La Haya - Paris 1973) 150.

8 J. Dubois et alii, Dictionnaire de Linguistique (Paris, Librairie Larousse 1973).

9 F. Lázaro Carreter, Diccionario de Términos Filológicos, $3^{\prime 1}$ ed. corregida
}

(Madrid, Editorial Gredos 1987) 207.

10 Outras línguas fazem corresponder ao género neutro (para além de seres inanimados) também os seres que não atingiram ainda a maturidade sexual. No Alemão, por exemplo, '‘Das Kind", 'a criança', é neutro. 


\section{Maria Carmen de Frias e Gouveia}

Se é mais fácil compreender a categoria de género ligada ao género natural propriamente dito, já se torna problemática a origem do género gramatical, que parece surgir, como foi dito, como um recurso sintáctico para expressar a concordância.

Os sistemas de género em Francês, Português, Espanhol, Alemão e Latim, por exemplo, são gramaticais. No entanto, e nos casos em que o género do substantivo não obedeça a normas claramente determináveis, poderá o mesmo reconhecer-se através da concordância com o artigo, o adjectivo ou o pronome.

Em virtude destas dificuldades relacionadas com os vários sistemas de género, alguns estudiosos discutem a validade, utilidade, ou mesmo necessidade da existência desta categoria. Referindo-se ao género, escreveu A. Meillet que a distinção não tinha significado na maioria dos casos, pois certos nomes abstractos são masculinos, outros femininos e outros neutros, sem que pareça haver uma razão clara para essas diferenças. E exemplificava, dizendo que em Francês, embora não o possamos facilmente explicar, "siège" é masculino e "chaise" feminino; e ainda que "soleil" é masculino e "lune" feminino; quando em Alemão, por exemplo, temos o contrário: fern. "Sonne" e mase. "Mond". Assim, «presque toujours denuée de sens [...] la distinction des genres grammaticaux était de plus incohérente dans la forme dès l'époque indo-européenne» ${ }^{1} \quad K$ Pelo que Meillet concluía que a categoria de género devia tender a uma redução, ou mesmo eliminar-se á medida que a língua evolui ${ }^{12}$.

Se, com efeito, nalguns casos o género gramatical pode parecer inesperado ou incongruente, o certo é que não é uma categoria inútil. Por outro lado, associou-se-lhe uma série de aspectos importantes ${ }^{12}$ : uma das suas funções gramaticais reside em assinalar a concordância, estruturando todo o grupo nominal e clarificando as relações, para além do que cumpre várias funções semânticas ${ }^{14}$. Basta pensarmos em alguns vocábulos do Português actual, tais como "banco" e "banca", ou "a polícia" e "o polí-

11 A. Meillet, “Le genre grammatical et félimination de la flexion" in Linguistique historique et linguistique générale (Geneve, Slatkine e Paris, Champion 1982) 202-203.

12 Idem, 204.

12 G. P. Zenenko, "Acerca de la manifestación del género de los sustantivos y adjetivos como categoría gramatical en las lenguas romances ibéricas" in Verba. Anuario Galego de Filoloxía, 10 (Universidad de Santiago de Compostela 1983) 230.

14 Miguel Gonçalves considera o género uma categoria semântica, para além de ser um princípio de classificação e variação flexional que o nome apresenta. Veja-se "Do vazio semântico à sexualização plena da categoria de género na linguística actual" in Diacrítica, 13-14 (Universidade do Minho 1998-1999) 303-330.

Faculdade de Letras | Universidade de Coimbra 
cia", que bem evidenciam a importância do género para distinguir significados.

Apesar de todas as dificuldades, reais ou aparentes, associadas à categoria de género, o certo é que tem vantagens reconhecidas, como o facto de permitir concordância e coesão do enunciado na redundância das marcas de género ${ }^{15}$, ou de determinar a estrutura morfológica de diferentes partes da oração, bem como as suas relações sintácticas ${ }^{16}$, o que lhe assegura o importante lugar que tem nas línguas românicas.

\section{Evolução do género na história da língua latina}

\subsection{O género das palavras em Latim}

É sabido que o primitivo Indo-europeu apresentava, no que se refere à declinação do nome, uma oposição entre "animado" (masculino e/ou feminino) e "inanimado" (neutro). Mas só alguns nomes estavam caracterizados como do primeiro tipo e, mesmo assim, havia várias oscilações.

Meillet explica ${ }^{17}$ que, no que respeita à forma, o género animado se opunha ao inanimado; mas, quanto à flexão, masculino e feminino em nada se distinguiam, tal como ocorria em Latim com a flexão de "mater" e "pater", ou ainda com o mase, "lupus" 'lobo' e o fern, "fagus" 'faia'. Assim, o carácter masculino ou feminino de um substantivo indoeuropeu só se reconhecia através dos adjectivos que se lhe referiam — tal como ocorria também em Latim ${ }^{18}$ - onde por vezes só a concordância do adjectivo ia marcar a diferença masculino / feminino.

No que se refere aos adjectivos, que ajudavam a distinguir estes dois géneros, a oposição era dada por uma diferença, não de flexão mas de tema: "nouus" - tema masculino e "noua" - tema feminino. Já a distinção entre ambos e o neutro era marcada através da flexão, que diferia nitidamente, embora se fizesse apenas nos casos nominativo, vocativo e acusativo.

\footnotetext{
15 M. Tereza Camargo Biderman, 1974: 134.

${ }^{16}$ G. P. Zenenko, 1983:231.

$\begin{array}{rccccccccccc} & \text { A. } & \text { Meillet, } & \text { "La } & \text { catégorie } & \mathrm{du} & \text { genre } & \text { et } & \text { les } & \text { conceptions } & \text { indo-européennes" } & \text { in } \\ \text { Linguistique } & \text { historique } & \text { et } & \text { linguistique } & \text { générale } & \text { (Genève } & \text { Slatkine } & \text { e } & \text { Paris, } & \text { Champion } & \text { 1982) }\end{array}$ 211-215.

18 Vejam-se os casos, p. ex., de "manus dextra" (fern.) ou de "beatus agricola"

(mase.): são os adjectivos que clarificam o género dos substantivos.
} 


\section{Maria Carmen de Frias e Gouveia}

Chegámos, então, ao Latim com a distinção de três géneros, em vez dos dois que actualmente possuem as principais línguas românicas (como o Português, o Espanhol, o Italiano ou o Francês). Além disso, os substantivos latinos repartiam-se por cinco declinações, como veremos ${ }^{19}$ :

A Ia declinação, de tema em -a, incluía sobretudo nomes femininos, como "rosa, -æ", adjectivos na forma feminina, como "alta", e femininos usados no plural, como "tenebrae" 'trevas', entre outros, podendo congregar também alguns masculinos, como "poeta, -ae".

A 2a declinação, de tema em -o, agrupava essencialmente os masculinos e os adjectivos na forma masculina (do tipo “bonus” 'bom'), ou neutra (como "bonum" 'bom'). Incluía ainda femininos como “Ægyptus, -i" 'Egipto', ou "ficus, -us" 'figueira'20, e alguns neutros, de que é exemplo "folium, -ii" 'folha'.

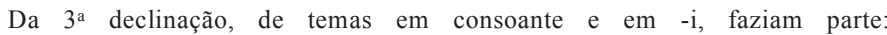
masculinos, como "dolor, -oris" 'dor', ou "uermis, -is" 'verme'; femininos, como "lex, legis" 'lei'; e neutros, como "lac, lactis" 'leite'. Também incluía os adjectivos de 2 a classe: "prudens", "utilis", etc.

Os nomes da $4^{\mathrm{a}}$ declinação, de tema em -u, eram normalmente masculinos, tal como "cantus, -us" 'canto'; mas podiam ser ainda femininos, como “manus, -us” 'mão', e neutros, como “genu, -us” ‘joelho'.

Por ultimo, a $5^{\text {a }}$ declinação, de terna em -e, incluía quase somente femininos, como "dies, -ei" 'dia'21, ou “res, rei” 'coisa'. Era masculino "meridies, -ei" 'meio-dia'.

Assim, e devido ao facto de cada declinação poder agrupar substantivos dos três géneros ${ }^{22}$, era muitas vezes o adjectivo que, no sintagma, clarificava qual o género do nome. ${ }^{*} 77$

19 Quanto aos adjectivos, embora se dividissem em duas classes, tinham uma flexão semelhante à dos substantivos, a saber: os da Ia classe, como "altus, alta, altum", correspondiam à $I^{\mathrm{a}}$ e $2^{\mathrm{a}}$ declinações; os da $2^{\mathrm{a}}$ classe, como "acer, acris, acre" 'acre; vivo, viva', "utilis, -e", ou "prudens" 'prudente', correspondiam à 3a declinação.

Relativamente aos nomes de árvores, podiam ser masculinos (como "pinaster" 'pinheiro bravo') ou neutros (como "buxum" 'buxo' e “sober" 'sobreiro'), mas eram fundamentalmente femininos: “abies" 'abeto', “cuprissus" 'cipreste', “malus" 'macieira', "platanum", etc. O fruto, por sua vez, era geralmente neutro: "ficum" 'figo', "malum" 'maçã', ou "pirum" 'pera', etc.

71 Este vocábulo podia ter dois géneros no singular (mase, ou fern.), mas no plural era sempre masculino.

77 Herculano de Carvalho, em Linguística românica. Morfologia (Coimbra, 1969)

6b, observa que as formas de masculino e feminino do Latim «valiam não apenas pelas relações de uma para outra, como pela relação que conjuntamente as opunha ao neutro».

Faculdade de Letras | Universidade de Coimbra 


\section{Considerações sobre a categoria gramatical de genero}

Numa visão de conjunto, temos que os nomes da $\mathrm{I}^{\mathrm{a}}$ e $5^{\mathrm{a}}$ declinações eram maioritariamente femininos, e os da $2^{\text {a }}$ e $4^{\text {a }}$ essencialmente masculinos, embora a nenhum dos géneros correspondesse uma declinação determinada. Por outro lado, se nem sempre os seres sexuados se podiam enquadrar no género masculino ou feminino - onde também poderiam incluir-se alguns inanimados -, do mesmo modo nem sempre um ser inanimado era identificado com o género neutro, como acabámos de ver.

Um aspecto importante é que entre os substantivos de tema em $\wedge$ a predominavam os femininos, e entre os de tema em $\wedge^{\wedge} \mathrm{o}$, os masculinos.

Estas considerações serão úteis para compreender o que diremos de seguida.

\subsection{Principais alterações operadas no Latim coloquial tardio (tradicional- mente designado "Latim vulgar") ${ }^{22}$ *}

Como pode depreender-se do exposto, a distinção dos três géneros, mais ou menos clara no Indo-europeu, em Latim começou a tornar-se débil desde cedo. Por outro lado, e devido à não total correspondência com os géneros "naturais", dá-se a decadência do neutro a favor, sobretudo, do masculino, como também se nota a tendência em repartir os nomes em masculinos e femininos «de acordo com os elementos formativos» ${ }^{24}$, isto é, segundo a sua terminação.

Por que razão se perdeu o neutro na evolução para as línguas românicas ${ }^{25}$ ? Parece ter sido o facto de as características da flexão se encontrarem sobretudo no final da palavra que levou a essa simplificação. Sendo geralmente o final pronunciado de modo mais fraco, essa marca tendia a abreviar-se ou a desaparecer. Acresce $o$ facto de as desinências do neutro e do masculino confluírem frequentemente ${ }^{26}$.

A diferenciação dos géneros masculino e feminino em relação ao neutro somente existia nos casos nominativo e acusativo - como

\footnotetext{
TI Preferimos utilizar aqui a expressão "Latim coloquial tardio" para evitar que a designação "Latim vulgar" possa, de algum modo, induzir o leitor em erro. 1988)182.

24 V. Väänänen, Introducción al latín vulgar, 3a ed. (Madrid, Editorial Gredos

25 Com excepção do Romeno.

26 Conclusões a que chegaram também Hernán Urrutia Cardenas e Manuela Alvarez Álvarez, Esquema de morfosintaxis histórica del español (Bilbao, Publicaciones de la Universidad de Dausto 1983) 72.
} 
explica Meillet ${ }^{27}$ - e era expressa pela própria flexão: por exemplo, a um nominativo (mase, ou fem.) “dulcís" “doce' e a um acusativo (mase, ou fem.) "dulcem" opunha-se, para ambos os casos, urna forma neutra única "dulce". Continuando a referir adjectivos (de valor semántico acrescido pelo facto de não existir artigo definido), a oposição masculino / feminino exprimia-se, não pela flexão, mas pelo tema; assim, os acusativos "bonum" e "bonam" não se podiam diferençar pela desinência mi (que, aliás, ambos tinham em comum), mas pelo facto de a palavra feminina ser de tema em -a e a masculina de tema em -o.

Por outro lado, na língua falada, o sistema já referido de cinco declinações acabava por ser, na realidade, constituído por dois grupos: o de tema em -a, para os femininos (que, além da antiga $\mathrm{I}^{\mathrm{a}}$ declinação absorvia os substantivos da $5^{\mathrm{a}}$, parte dos da $3^{\mathrm{a} 28}$ e até da $4^{\mathrm{a}}$ ), e o de tema

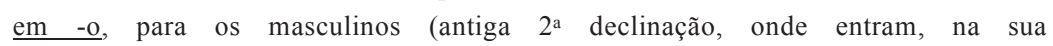
quase totalidade, os nomes da 4 a).

Em suma: havendo alguma indistinção, ao que se vinha associar a evolução fonética resultante da perda das desinências casuais, e a redução das declinações antigas, o neutro acabou por desaparecer. Constituiu esta mudança uma das mais importantes ocorridas no Latim coloquial tardio. Desaparecido o neutro, os géneros do Português ${ }^{29}$ derivam do facto de as palavras de tema em $<>$ serem normalmente masculinas e as de tema em $\wedge$ a femininas, passando os temas (latinos) a desinências (do Português), entendidas estas como morfemas indicadores de género ${ }^{30}$.

Vista a evolução ocorrida neste período $^{31}$ no que diz respeito ao género, consideraremos agora como se foi processando em Português arcaico essa repartição dos géneros, tendo como ponto de referência o Latim.

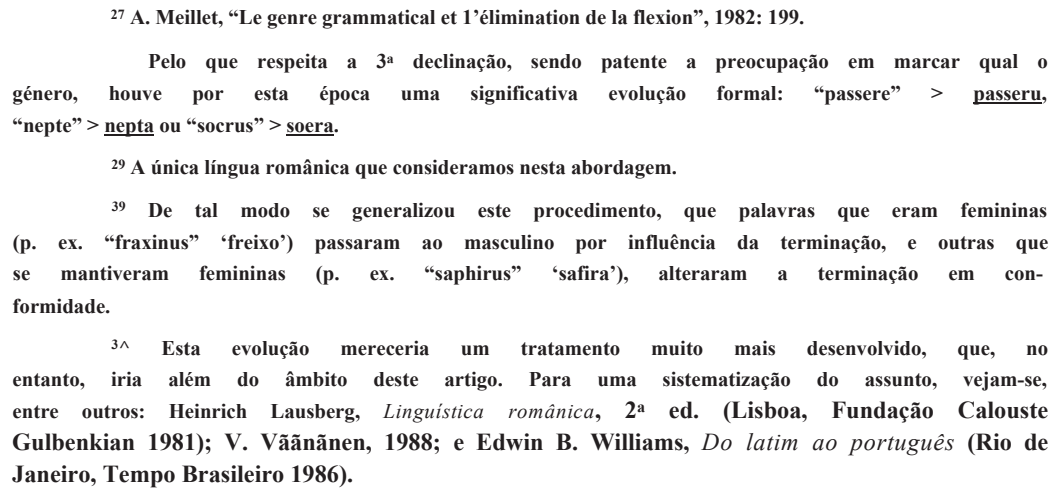




\section{Considerações sobre a categoria gramatical de género}

\section{O género em Portugués arcaico ${ }^{32}$}

Se já em Latim era complexa a "arrumação genérica" 33, continuará a sê-lo na fase medieval da historia da língua portuguesa. $\mathrm{Na}$ sequência do que já se verificava em Latim tardio, o Português arcaico conhece unicamente dois géneros - mas estes nem sempre eram correspondentes ao que a palavra tinha em Latim ${ }^{34}$.

Por outro lado, é importante lembrar que também já daí decorria a hesitação de género em alguns vocábulos como: "lepor, -õris" 'lebre', ou "finis, -is" 'fim'35.

Mantêm o género etimológico muitos substantivos e adjectivos, como: os que terminavam em $-\mathrm{u}$ no masculino $\mathrm{e}$ em -a no feminino, tais como "filius" / "filia", "delicatus" / "delicata"; os vocábulos cujo género era dado por heteronímia ("pater" / "mater") ou por derivação ("imperator" / "imperatrix"); e ainda muitos outros substantivos, provenientes de várias declinações latinas.

Como fica bem explícito no Ponto 2.2., recebemos (em especial vindos da $3^{\text {a }}$ declinação) alguns substantivos já com prévia alteração de género: primitivamente mase, tinham já passado a fern, “ordo, -Inis" 'ordem' e “torrens, -entis" 'torrente', entre outros substantivos; o inverso acontecera com "echo, echus" 'eco' ou "uallis, -is" 'vale', já masculinos em Português.

Para a análise que se segue, iremos partir de uma observação consideravelmente mais pormenorizada do que a de Rosa Virgínia de Mattos e Silva ${ }^{36}$.

\footnotetext{
32 Curiosamente, muitos dos aspectos que se encontram nesta fase da língua são visíveis na linguagem popular. Cf. Maria Carmen de Frias e Gouveia, "Algumas observações sobre a linguagem popular e regional no que se refere à categoria de género. Retlexos do género gramatical do português antigo na linguagem popular" in Atti del XXI Congresso Internazionale di Linguística e Filologia Romanza (Tübingen, Max Niemeyer Verlag 1998), 11,339-349.

${ }^{11}$ Cf. Martins Sequeira, Aspectos do português arcaico (Lisboa, Livraria Popular
} 1943)130.

${ }^{34}$ Cf. o mase, "color, -oris" > 'a cor' e o fern, "porticus" > 'o_pórtico\

Daqui pode derivar também a falta de correspondência actual entre as línguas românicas. Ver a este propósito H. Lausberg, 1981: 269-271.

36 R. V. Mattos e Silva, em Estruturas trecentistas. Elementos para uma gramática do português arcaico (Maia, Imprensa Nacional - Casa da Moeda 1989) 113-118, distingue: 1. os nomes de género único (como a ajuda, o acrescentamento, o lenguagem, $a$ fim, a valor), 2. nomes de dois géneros, com flexão redundante (como o mancebo / a manceba, o filho / a filha, o meestre / a mestra; e na altura sem flexão redundante senhor, ajudador, 


\subsection{Palavras em -agem (com as seguintes variantes gráficas: -age, - agë, -agen, -aie, -aien, -ajem, -ajeë, etc.)}

Podem derivar, entre outras possibilidades ${ }^{37}$, da terminação
latina -ago, -agine, como "imago, -mis" 'imagem', ou "origo, -Inis" 'ori-
gem', ambas femininas, o que poderá explicar o feminino actual. No entanto, já em Latim se verificava hesitação de género ${ }^{38}$.

Muitas palavras deste tipo chegaram-nos por via francesa, onde são sempre masculinas ${ }^{39}$, tendo mantido o género no Português $\operatorname{arcaico}^{40}$, situação que se opõe à do Português actual, que preferiu as formas femininas. Mais raramente, podem derivar da terminação latina $z$ $\underline{\text { aticum }}^{41}$.

Se é certo que o Português antigo apresenta destas palavras muitas vezes masculinas, é também verdade que se tem generalizado demais esse facto: a par de formas com o género masculino, surgem também muitas outras com o género feminino etimológico, admitindo-se, frequentemente, ambos. Martins Sequeira ${ }^{42}$ diz que eram masculinas as que se constituíam por derivação, como linguage, linhage, etc. Mas acres-

sabedor, burguês), e 3 . nomes de dois géneros sem flexão redundante (seu sergente, hua sergente, a par de, com flexão redundante, sergenta, como surge no Orto do Esposo). A Autora segue a mesma divisão em $O$ Português arcaico. Morfologia e sintaxe (São Paulo, Contexto 1993) 17-20.

37 De facto, as origens podem ser várias: homenagem pode provir do prov. “omenatge" ou derivar do fr. "omenage" (do Latim "*hominaticu-"); mensagem, portagem e linhagem entraram através da língua francesa; linguagem e viagem derivam respectivamente do prov. "lenguatge" e "viatge" (esta últ. do Latim "uiaticu-").

38 'Margem', por exemplo, podia ser em Latim ("margo, -inis”) do género feminino ou masculino.

39 Como exemplo, cf: fr. "le voyage", "le paysage", "le langage"; esp. "el viaje", "el paisaje", "el lenguage"; it. "il viaggio", "il paesaggio", etc.

40 No entanto, Rodrigues Lapa, no Vocabulario galego-português. Extraído das Cantigas d'escarnho e de mal dizer ([Vigo], Editorial Galaxia 1970, apresenta esta terminação como «normalmente feminina», dando o exemplo de peage(n), e contrapondo linhage como masculino. Manuel de Araújo, em O livro da montaria de D. João I. Glossário $e$ comentário filológico. Dissertação de licenciatura [inédita] apresentada à Faculdade de Letras da Universidade de Coimbra em 1943, p. 359, nota que «as palavras terminadas em agem são do género feminino» («que seria grande a sua auantagem»), excepto «linhagem que é do género masculino».

41 Joseph Piel aponta um único adjectivo em -agem: a forma 'selvagem', de "siluaticu-". Cf. a p. 216 do artigo "A formação dos substantivos abstractos em português" in Biblos, XVI, I (Coimbra, Coimbra Editora 1940) 209-237.

42 Cf. Martins Sequeira, 1943: 92.

Faculdade de Letras I Universidade de Coimbra 
centa que surgia muitas vezes a forma feminina em a message, a promage 'a plumagem', a menage ${ }^{43}$.

Assim, e perante uma análise de ocorrências, podemos comprovar que, nesta época, é possível encontrar vocábulos terminados em 2

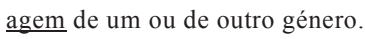

Surgem desde inícios do século XIII, sendo ligeiramente mais antigo o emprego do masculino: «foi quant'ir podia / aa mui briosa / abadess'e seu message contou...» (Cantigas de Santa Maria, 195. 156, p. 24344); «e falan todos lenguages ... de fazer que os lenguages entendan ... mais foilles Deus toller / os lenguages, assi que un a outro non entenden» (Ibidem, 427. 40, 46, 5145); «A que do bon rey David / de seu linnage decende» (Ibidem, 6. ${ }^{46}$ ) ou «E se ella casar cõ alguu que non seya conuenauil a ella ne per seu linage, ou se se for cü algue en maneyra que seya onta della ou de seu linage, seya outrosy deserdada...» \{Foro Real, III, $\left.38-40^{47}\right)$.

O género feminino começa a ser mais frequente a partir do século XIV: «de toda pilhaiem que tomarem...» ${ }^{48}$; «desvairadas $\mathrm{p}$ ru magens ${ }^{49}$; «qvando Talamô oyo a messagen» ${ }^{50}$; «pella homenagee que me ten feyta» $51 ;$ «... das uiagens que fezerem» (Descobrimentos Portugue-

4 * Idem. A propósito, o A. explica em nota que a expressão «torre de menagem»se obteve por fonética sintáctica, fruto da crase do artigo com a vogal inicial.

44 Edição de Walter Mettmann das Cantigas de Santa Maria, de Afonso X, o Sábio, vol. II (Coimbra, Acta Universitatis Conimbrigensis 1961) 242.

45 Idem, vol. Ill, 1964:413.

46 Idem, vol. I, 1959:21.

47 José de Azevedo Ferreira, Afonso X. Foro Real., vol. I - Edição e estudo linguístico: vol. II - Glossário. (Lisboa, Instituto Nacional de Investigação Científica 1987) 198.

48 Descobrimentos Portugueses, vol. I. Documentos para a sua história publicados e prefaciados por João Martins da Silva Marques (Lisboa 1944) 190.

49 Livro de Falcoaria de Pêro Menino. Publicado com introdução, notas e glossário por Rodrigues Lapa (Coimbra 1931) 36.

Crónica Troiana. Edição de Ramón Lorenzo (A Coruña, Fundación Pedro Barrié de la Maza, Conde de Fenosa 1985) 237. Nessa obra, a par do fern., surge como mase, em «pois que ... ouuo acabado seu mesaie». Mas de novo encontramos o feminino na Demanda do Santo Graal. Edição de Joseph-Maria Piel. Concluida por Irene Freire Nunes (Lisboa, Imprensa Nacional - Casa da Moeda 1988).

^ Colección Diplomática de Galicia Histórica, I: 296. Citação extraída do Glossário de La traducción gallega de la Crónica General y de la Crónica de Castilla, vol II. Edición crítica anotada, con introducción, índice onomástico y glosario, por R. Lorenzo (Orense, Instituto de Estudios Orensanos "Padre Feijoo", 1977). Abonação de um documento de 1326. 
ses, p. 58) $)^{52}$; «segundo a lîguagem de Portugal» (Crónica Geral de Espanha de 1344, cap. CCCLXXXIV, 1.753), etc.

Depois desta data, passou a ser muito comum encontrar-se a hesitação do uso do género ${ }^{54}$. Inclusivamente, num documento de 1400 lê-se: «segundo o pleito et $\underline{o}$ menajee $\ldots$ et segundo a menajee que me sobre ello tenen feita» ${ }^{55}$,o que mostra que tal ocorrência dúplice era possível num mesmo documento. O mesmo acontece em $A$ Demanda do Santo Graal 56: «eram da linhagem de Persival» (cap. 216, p. 173) e «E por esto era aquel linhagem atam honrado» (cap. 37, p. 43).

A mesma situação está patente na Coronica do Condestabre ${ }^{57}$, e nesta passagem de um texto do séc. XV: «a dita portageen $\cdots$ o dito portageen» ${ }^{58}$.

Um caso interessante é o facto de a palavra origem aparecer como masculina no séc. XVI, ao contrário do que pressuporia o étimo ${ }^{59}$; contudo, no mesmo século encontra-se também o feminino ${ }^{60}$. Parece que, também neste caso (e apesar de a forma ser já feminina em Latim), é manifesta a hesitação quanto ao uso do género.

52 Parece surgir, no entanto, como substantivo masculino no século XIII, nas Cantigas de Santa Maria, vol. II, p. 318: «aquel vi age / fez com'é usage».

53 Edição crítica (fac-similada da ed. de 1961) do texto português, por L. F. Lindley Cintra (Lisboa, Imprensa Nacional - Casa da Moeda 1984).

54 Ramón Lorenzo, 1977: 831, apresenta muitos exemplos de ocorrências do vocábulo com ambos os géneros. Cf. $\mathrm{s}$. u. "lengoage, lenguage, linguage" e "linage, linagem, linage, linhaie".

$$
55 \text { Colección Diplomática de Galicia Histórica, I, 611. Citação igualmente extraída }
$$
de R. Lorenzo, 1977.

56 Joseph Piel, 1940.

52 Adelino de Almeida Calado, Estoria de Dom Nuno Alvrez Pereira. Edição crítica da "Coronica do Condestabre" com introdução, notas e glossário por ... (Coimbra, Acta Universitatis Conimbrigensis 1991). Podemos citar, a título de exemplo, estes dois excertos: «e toda sua linhagem» $\mathrm{e}$ «... e as muytas merçees que seu linhagem delle recebera».

58 R. Lorenzo, 1977, s. u. "portage".

59 Por exemplo na Crónica do Palmeirim de Inglaterra, de Francisco de Morais, cap. LIV, p. 372: «ainda alli parecia abranger as reliquias do orige donde procedia». Citação recolhida em Celeste Fernanda Souto Pinto, Ensaio sobre o Palmeirim de Inglaterra (Dissertação de licenciatura [inédita] apresentada à Faculdade de Letras da Universidade de Coimbra em 1949) 65-66.

60 Itinerario da Terra Sancta e suas particularidades. Composto por Fr. Pantaleão de Aveiro, $7^{\text {a }}$ edição conforme à primeira (Coimbra, Imprensa da Universidade 1927) 508, 1.21: «sua origem he de hua fonte de muyta agua». 


\section{Considerações sobre a categoria gramatical de género}

Em suma, as palavras em -agem só a partir do século XVI começaram a adoptar o género feminino que actualmente conservam, e que Fernão de Oliveira considerava o mais aconselhável para este tipo de vocábulos ${ }^{61}$.

\subsection{Palavras em -ês (com as variantes gráficas: -es e -ez)}

Estas formas podem ser substantivos ou adjectivos. As mais dignas de menção são aquelas que podem funcionar como adjectivos e que, no Português arcaico, se documentam geralmente como invariáveis: é o caso de "burgués", "francez", "fregués", "genoes", “ingles" ("ingres" e "engles"), "português", etc., como se depreende dos exemplos documentados: «... pela parede Francez do fundo do sotom» (Doc. de

S. Tiago de Coimbra, de 132462), «domde ella he fregués com seu jrmãao...» \{Doc. 42, de Março de $1463 \quad{ }^{63}$ ) ou «per linguagemJadinha portuguez» $64 *$.

Se é frequente o emprego como invariável nos séculos XIV e $\mathrm{XV}$, é já possível documentar, na segunda metade do séc. XIII, formas de feminino analógico, que aparecem também ao longo deste período. Vejase, por exemplo, «düa burgesa $^{63}$ / nobr'e cortesa» (Cantigas de Santa Maria, 255. 1 2, 1366), ou ainda «... a pe dun mont'está / en que muitas cabras montesas á»" (Ibidem, 52. 16 $6^{67}$ ). Não deixa de ser curioso o feminino analógico de "cortes" e "montes", hoje palavras uniformes na língua padrão.

61 Fernão de Oliveira, Gramática da linguagem portuguesa. Edição fac-similada (Lisboa, Biblioteca Nacional 1988) cap. XLíV.

62 Extraído de Fr. Joaquim de Santa Rosa Viterbo, Elucidario das palavras, termos e frases que em Portugal antigamente se usaram e que hoje regularmente se ignoram... Ed. crítica baseada nos manuscritos e originais de Viterbo por Mário Fiúza. Vol. II (Porto Lisboa, Livraria Civilização 1984), s. u. "parede francez".

63 Citação colhida de J. J. Dias, A. H. de Oliveira Marques e Teresa F. Rodrigues, Álbum de paleografia (Lisboa, Editorial Estampa 1987) 81.

${ }^{64}$ Ordenações do Senhor Rey D. Affonso V (Coimbra 1792), II, 93, I, 513.

${ }^{63}$ Aqui empregue como substantivo.

66 Cf. Walter Mettmann, 1964: 12. J. P. Machado, no Dicionário Etimológico da Lingua Portuguesa, 4a ed. (Lisboa, Livros Horizonte 1987) atribui a "cortesa" o séc. XIV; mas trata-se de uma forma anterior, como se vê pelas Cantigas de Santa Maria, do séc. XIII, onde surge diversas vezes.

67 W. Mettmann, 1959: 149.

Faculdade de Letras | Universidade de Coimbra 


\section{Maria Carmen de Frias e Gouveia}

Ao longo do século XVI é já usual encontrar o feminino analó$\operatorname{gico}^{6 \wedge}$. No entanto ainda é possível documentar neste século as formas invariáveis* 69 *, e também mais tarde, embora esporadicamente.

\subsection{Palavras em -nte}

Seguindo a herança do Latim (p. ex. "infans, -antis” era aplicável a ambos os sexos), estas palavras mantiveram-se geralmente uniformes durante este período. Assim, creente, $\underline{\text { infante }}^{79}$ e muitos outros vocábulos podiam aplicar-se indiferentemente a um ou outro género. De entre muitos exemplos recolhidos, aponte-se o seguinte: «hûa infante, filia dun rei» (Cantigas de Santa Maria, 122. $\mathrm{I}^{71}$ ). Esta situação ainda é corrente no século XVI ${ }^{72}$.

Segundo Ramón Lorenzo, desde o séc. XII surge a forma analógica infanta, embora esporadicamente, em textos redigidos em Latim, começando, depois, a aparecer com maior frequência: «... que aueran por señora a infanta doña Maria»" (A. López Ferreiro, Historia de la Santa A. M. Iglesia de Santiago de Compostela, Vil, Apénd. 1373).

As palavras parente (de "parens, -entis") e obediente (de “oboediens, -entis") etimológicamente uniformes, apresentam, por sua vez, formas femininas desde o século XIII: «aa Virgen santa que Deus fillou por parenta» (Cantigas de Santa Maria, 349. 374); «titulo dos que casan cü sas parentas ou cü molheres d'ordï» (Foro Real, IV. $8{ }^{75}$ ), e ainda «a mia serventa leal» (Cantigas de Santa Maria, 216. 4676), entre muitos outros exemplos. Pelo que diz respeito ao século XIV, Clarinda

${ }_{00}^{r 0}$ Por exemplo em Camões, Os Lusíadas. Ed. comemorativa do IV Centenário da sua publicação (Lisboa, Instituto de Alta Cultura 1972) VII, 72, ou no próprio título da Gramática da lingoagem portuguesa, de Fernão de Oliveira.

69 Como nas Décadas de João de Barros. Ou ainda em Gil Vicente (Auto da Fama): «... e balhando à mourisca / dentro gente português», in António José Saraiva, Teatro de Gil Vicente, 6; 1 ed. (Lisboa, Portugália Editora) 209, v. 57.

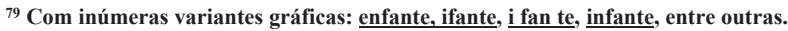

71 Walter Mettmann, 1961: 60.

77 «Da ifante o delicado, / Singelo e brando peito / Vence se ora de amor, ora de medo» (Sá de Miranda, 150, 479): citação recolhida em Carlota Almeida de Carvalho, Glossário das poesias de Sá de Miranda (Lisboa, Centro de Estudos Filológicos [1939]), s. u. "ifante, infante".

73 Citação recolhida em Ramón Lorenzo, 1977: 728.

74 W. Mettmann, 1964:244.

7"' Edição de José de Azevedo Ferreira, atrás citada.

76 W. Mettmann, 1961:292.

Faculdade de Letras | Universidade de Coimbra 


\section{Considerações sobre a categoria gramatical de género}

Maia regista obedijnta $^{77}$. A partir desta altura, o feminino analógico começou a generalizar-se na maioria das formas.

No entanto, infante encontra-se registado com ambos os géneros no Grande Dicionário da Língua Portuguesa 78 de Cândido de Figueiredo.

Nem sempre seguiram o género etimológico ${ }^{79} *$ os vocábulos do tipo fonte $(<$ "fons, -ontis" mase.), fronte $(<$ "frons, -ontis" fern.), ponte (< “pons, -ontis" mase.), torrente $(<$ “torrens, -entis" mase.), etc. Por exemplo, ponte aparece já como feminino em documento do século IX 89 segundo aponta Leite de Vasconcelos, enquanto que torrente «na língua antiga foi masculino» ${ }^{81}$.

\subsection{Palavras em -ol}

Do estudo feito parece depreender-se que estes vocábulos se mantiveram uniformes na fase arcaica do Português. Contudo, somente se encontraram abonações para "espanhol" 82 .

No século XV documentam-se «lingoa espanhol» e «molher espanhol» ${ }^{83}$, e ainda no século XVI lemos em André de Resende «a boa gente espanhol» ${ }^{84}{ }^{*}$, pelo que podemos deduzir que a generalização do feminino analógico se deu numa época posterior.

77 Clarinda de Azevedo Maia, História do galego-português. Estado linguístico da Galiza e do Noroeste de Portugal desde o século XIII ao século XVI (Com referência à situação do galego moderno). (Coimbra, Instituto Nacional de Investigação Científica 1986). Referência colhida do Doe. $n^{\circ} 143$, p. 254.

78 Cf. 23a edição. (Venda Nova, Livraria Bertrand Ed. 1986), s. u. "infante".

79 As palavras da $3^{\text {a }}$ declinação latina estavam mais sujeitas a discrepâncias e hesitações de género, por não terminarem em -a ou -o, usualmente entendidas como desinências de fern, e mase., respectivamente.

${ }^{89}$ Cf. Opúsculos, vol. I (1928): Filologia, Parte Ia : 290.

81 Antenor Nascentes, Dicionário Etimológico da Língua Portuguesa, 2a ed. (Rio de Janeiro 1955) 776, s. u. "torrente", onde remete para Frei Pantaleão de Aveiro, Itinerário, 2 a ed., 40.

82 J. P. Machado diz a esse respeito: «Espanhol, adj. e s. Parece tratar-se de um lat. “*hispaniolu-", diminutivo de "hispanus" [...]». É também a opinião de A. Nascentes, 1955.

83 Citações colhidas em Dulce de Faria Paiva, História da lingua portuguesa. II: Século XVe meados do século XVI (São Paulo, Editora Ática 1988) 43.

$8^{\wedge}$ Citação extraída de José Joaquim Nunes, Compêndio de gramática histórica portuguesa (Fonética e morfologiaJ, 9ª ed. (Lisboa, Clássica Editora 1989) 225, nota 2. 


\section{Maria Carmen de Frias e Gouveia}

\subsection{Palavras em -or}

Os substantivos abstractos em -ore- eram masculinos em Latim. Segundo Väänänen ${ }^{85}$, no Latim tardio da Gália e da Ibéria houve tendência em torná-los femininos, para os diferenciar dos substantivos concretos masculinos da mesma terminação: auctor, censor, senior, suasor, traditor, etc.

Assim, eram etimológica e inicialmente masculinos: ardor, $\underline{\text { calor, }} \underline{\text { cor }}$ (de "colore-"), $\underline{\text { dor }}$ (de "dolore-"), $\underline{\text { error, }}$ fervor, horror, labor, pavor, rigor, sabor, valor, e muitos outros ${ }^{86}$. A maioria manteve-se masculina, mas o Português arcaico apresenta já algumas hesitações de género, e algumas destas formas acabaram definitivamente por se fixar na forma feminina ${ }^{87}$; outras, no entanto, conservaram o masculino etimológico.

Nesta época documenta-se largamente essa hesitação de género, como se pode depreender dos exemplos seguintes, colhidos de uma extensa lista de vocábulos deste tipo ${ }^{88}$ : «na aluor» (Afonso X, Primeyra Partida, VII, 235, p. 178 ${ }^{89}$ ), a par de «tu es alva dos alvores» (Cantigas de Santa Maria, 340. 1290); e ainda: «ssa suor» (Afonso X, Primeyra Partida, IV, 57, p. 8291), e também no século XV, «depois que ouverõ suas caras alimpadas do poo e da suor» (Crónica Geral de Espa-

86 Cf. 1988: 238. Zenenko crê que essa mudança de género se deve à confusão com outros substantivos, geralmente femininos, em -ura, já que coexistiam em Latim formas do tipo "feruorem" e "feruura".

ồ Joseph Piel, 1940: 219 considera que a terminação -or era inicialmente usada com temas verbais, como am+or, tim+or, horr+or. Uma vez que existiam abstractos em -or a que correspondiam adj. em -us ("albore" podia interpretar-se como derivado de "albus"), criaram-se por falsa analogia novos abstractos, como "lent+or". Em Português antigo encontramos alvor, amargor, frescor, etc., mas são mais frequentes hoje as formas em -ura (amargura, frescura, etc.).

87 Antenor Nascentes, 1955: 212, s. u. “côr, diz que o Português e o Francês «trocaram o género latino de côr». O Espanhol mantém, com efeito, o mase, el color, el dolor, etc.

${ }_{00}^{00}$ No caso de valor, no entanto, parece tratar-se mais de uma distinção de sentido do que mera hesitação. Nas Cantigas de Santa Maria surge como masculino, quando relacionado com bens materiais, e é feminino se referido aos valores da alma: «non perdeu o orne bõo valor de tres dyeiradas», 323. 38, vol. III, p. 181; e «sa bondad'e ssa mesura e seu prez e ssa ualor", 202. 10, vol. II, 259.

OQ

Edição de José de Azevedo Ferreira (Braga, Instituto Nacional de Investigação Científica 1980).

99 Walter Mettmann, 1964: 222.

${ }^{9} 1$ Cf. nota 4 desta página.

Faculdade de Letras | Universidade de Coimbra 


\section{Considerações sobre a categoria gramatical de género}

nha de 1344, cap. CCCLXXIV, p. 13892), a par do masculino, já empregue por Frei João Alvares, em «que no suor do seu rostro» (I, 53, 1. 11$\left.-12^{93}\right)$. Parece que, no caso de suor, o género masculino foi-se progressivamente fixando ao longo do séc. XV, surgindo ainda o feminino no

Virgeu de Comolaçom.

Dentro deste tipo de vocábulos outros há que, de um modo ou de outro, seguem o género etimológico, como: louvor (loor), de *laudore (fern, no Latim clássico "laus, -dis") que também assim aparece no Português antigo: «per que sa loor tornada» (Cantigas de Santa Maria, 294); dor, como aponta também Ramón Lorenzo, é geral mente feminina ${ }^{95}$, embora possa surgir com o masculino etimológico: «todo o dor luxurioso") (Boosco Delleytoso, cap. $\left.{ }^{\mathrm{I}}{ }^{96}\right)$; e nas Cantigas de Santa Maria, error surge sempre como substantivo masculino ${ }^{97}$ : «porque leixes teus errores» $\left(152.29^{98}\right)$.

Sempre com o género feminino aparecem, por exemplo, «muita maa cheiror» (Cantigas de Santa Maria, 102. 4599); «ao çeo semella quand'é con sas esplandores» \{Ibidem, 384. 18100); «Sabede que eno mundo non ha ençenço nen frol nen balsamo nen outra cousa que tan bõa

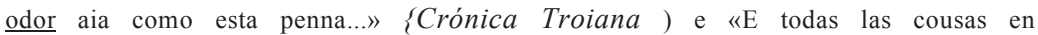
el conthiudas queden firmes e valla en sua uigor» (Doc. 136, de 1506 ${ }^{101}$ ).

Ainda com a mesma terminação, e empregues tanto como substantivos como adjectivos, temos os adjectivos latinos terminados em ore, que eram invariáveis, sendo do mesmo modo usados no Português

92 Edição de L. F. Lindley Cintra.

92 Citado por Maria Miquelina Botelho Antunes, $O$ vocabulário de Frei João Alvares. Estudo lexicográfico. Dissertação de licenciatura [inédita] apresentada à Faculdade de Letras da Universidade de Coimbra, em 1961, p. 23.

94 Estranhamente, Walter Mettmann dá o vocábulo como masculino na p. 177 do Glossário, vol. IV, 1972.

95 1977: 501, s. u. “door”. Rosa V. de Mattos e Silva, na sua obra O Português arcaico (anteriormente citada), aduz que ao estudar os Diálogos de S. Gregário (séc. XIV) encontrou a forma dor 29 vezes no género feminino e 1 só vez no masculino.

9^ Citação extraída de Antenor Nascentes, 1955: 255, s. u. “dor”.

97 A par desta forma, nas Cantigas de Santa Maria documentam-se erro e erra com o mesmo sentido: «eno juyzo... uos ache sen erro e sen pecado» (79. 54) e «dali adeante sempre serviu de grado / a Virgen Maria sen faliment'e sen erra» (193. 63).

98 W. Mettmann, 1961: 141.

99 Idem, 1961: 4.

$100 \quad$ Idem, 1964:326.

101 Clarinda Maia, 1986:244. 


\section{Maria Carmen de Frias e Gouveia}

arcaico. Assim, e a título de exemplo para o feminino ${ }^{102}$ *: "por a donzela que foy mia senhor» (Joan Soares Somesso, $\mathrm{n}^{\circ} 377$ do Cancioneiro da Ajuda $\left.^{\wedge}\right) \mid$ «aues caçadores» (Orto do Esposo, 44, 17104); «E a dita comdessa era em ello comsemtidor» (Crónica de D. „João /, cap. CLXXVIII, p. 383105); «besta ladrador» (Demanda do Santo Graal, 195, p. 154) ou «ta bandeira vencedor» (Leal Conselheiro, cap. XCIX ${ }^{106}$ ).

Casos houve em que o Português arcaico criou femininos analógicos, com terminação -a, que surgem esporadicamente na segunda metade do séc. XIII: «U lhe quis chamar senhora / chamou-lhe Dona Gontinha» (Cantigas d'escarnho e de mal dizer, 63. 27); «Nunca se Deus mig'averrá, / se mi non der mia senhora» (ibidem, 63. 27107). Clarinda Maia ${ }^{108}$ refere que senhora surge já, e mais que uma vez, no Doc. 147 ( 1448) que transcreve; enquanto que no Doc. 150 (1484) senhora e senhor coexistem no mesmo texto. Esta situação (documentada num texto separado 35 anos do que mencionámos em primeiro lugar) testemunha, ao longo do séc. XV, o uso comum e simultâneo de ambas as formas, a anteceder a total generalização do feminino analógico que o século seguinte trará.

Desde cedo se desenvolveu, portanto, uma forma analógica, que, após coexistência com a invariável, acaba por se fixar definitivamente ao longo do século XVI.

\subsection{Palavras terminadas em -e: seus femininos}

Fruto de processos herdados do Latim, são já comuns no séc. XIII as terminações: $<$ ) para o masculino $\mathrm{e}^{\wedge}$ para o feminino.

102 Dada a grande quantidade de material a este propósito recolhida, citam-se algumas das muitas abonações possíveis. Para outros exemplos ver $M$ Carmen de Frias $e$ Gouveia, 1993: 50-54.

103 Edição de Carolina Michaelis de Vasconcelos. Reimpressão da edição de 1 lalle (1904), acrescentada de um Prefácio de Ivo Castro e do Glossário das cantigas (Revista Lusitana, XXIII) (Lisboa. Imprensa Nacional - Casa da Moeda 1990) vol. I, p. 742.

10^ Edição de Bertil Maler. Vol. Ill: Correcções dos vols. I e II, estudo das fontes e do estado da língua, glossário, lista dos livros citados e índice geral (Stockholm, Goteborg e Uppsala, Almqvist \& Wiksell 1964) 56.

10^ Fernão Lopes, Crónica de D. João /. I vol: segundo o códice $\mathbf{n}^{\circ} 352$ do Arquivo Nacional da Torre do Tombo. ([Porto], Livraria Civilização Editora 1983).

100 Tradução de um hino latino, por D. Duarte, e incluida no Leal Conselheiro (Lisboa, Typographia Rollandiana 1843) 320.

107 Para ambas as citações ver M. Rodrigues Lapa, Vocabulario galego-português. Extraído das Cantigas d'escarnho e de mal dizer (já citado), p. 96, s. u. "senhora".

108 Clarinda Maia, 1986: 658.

Faculdade de Letras i Universidade de Coimbra 


\section{Considerações sobre a categoria gramatical de género}

Também formaram os femininos em -a as palavras terminadas em -e: (erege / ereja, monge / monja, etc.): «e ere ¡a a chamavon» (Cantigas de Santa Maria, 89. 58 $\left.8^{109}\right)$.

Alguns destes femininos ( $\underline{\text { monja, }}$, p. ex.) irão manter-se na evolução da língua; enquanto outros serão meramente utilizados na linguagem popular.

\subsection{Palavras provenientes do antigo neutro latino}

$\mathrm{Na}$ sua maioria, são masculinas ${ }^{110} 111$ *. É o caso de animal ("ani-

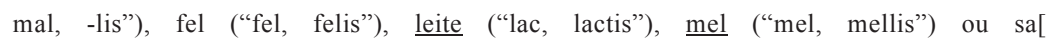
("sal, salis" - já por vezes também mase.).

Devido à terminação em $\wedge$ a nos casos nominativo e acusativo, o plural neutro, geralmente identificado com o feminino, acabou por tomar esse género. Tal feminização, que se verificava já no Latim tardio, veio dar origem a novas formas, agora do feminino singular, cujo plural se fazia com -s. Exemplifiquemos alguns destes casos: «penssou que un mõesteiro / faria con bõa claustra, igreja, e cymiteiro, / estar e enfermaria» (Cantigas de Santa Maria, 45. $28^{11}$ !), e «a vos, Dona abadessa, / ... estas doas vos envio» (Cantigas d'escarnho e de mal dizer, 167. $5^{112}$ ).

Do antigo neutro latino em $\underline{\text {-men }}(>*$-minem $)$ temos actualmente formas masculinas, cujo género, no Português arcaico, podia, no

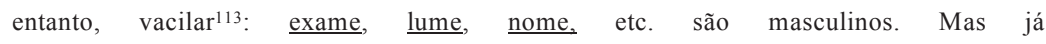
'legume' aparece como feminino no séc. XIV — «centeo ou ffarinha ou outra legumha algua»" (Descobrimentos Portugueses, I, 54). Segundo Leite de Vasconcelosi14, a forma leguma (e suas variantes gráficas:

109 Walter Mettmann, 1959: 258. Lembre-se, a propósito, que nas Cantigas de Santa Maria, 157. 2, existe "ospeda", mas com um sentido diferente de "ospede": 'hospedeira'. Cf. vol. II, p. 151.

110 Como excepções, há a registar, entre outras, colher ("cochlear"'); e mar ("mare, -is"), só posteriormente tornada masculina.

111 Walter Mettmann, 1959: 131.

11 ?itado por M. Rodrigues Lapa, 1970, s. u. "doa".

113 Cf. Urrutia Cardenas e M. Alvarez Alvarez, 1983: 68-70; e G. P. Zenenko, 1983: 239-240. Com efeito, com a perda do neutro, e tendo as línguas românicas ibéricas uma clara oposição -o mase. / -a fern., os nomes que apresentavam terminação diferente acusavam uma certa variação de género. O último A. (1983: 239) considera mesmo que o Latim não havia ainda atribuído um género definitivo a estas palavras.

114 Revista Lusitana, XXVII, 251. É também a opinião de Ramón Lorenzo, 1977: 751, s. u. "legumas, legumhas, legumyas". 


\section{Maria Carmen de Frias e Gouveia}

leguinias, leguimhas e legumhas) deriva de legumina, plural neutro coin sentido colectivo ${ }^{115}$.

Alguns nomes latinos dispunham para o plural de $\underline{\text { um colectivo }}$ em -a, o que deve estar na origem deste emprego, como em: «Que lhi dava acta, e de todo o ffeito e o processo por apostolos» (Doc. de 1315, do Salvador, de Coimbra ${ }^{116}$ ), com evidente carácter de colectivo. Nessa situação estão também palavras que raramente tinham uso no singular, como elementa (cf. também J. P. Machado); veja-se ainda igrejairo, referido por Viterbo ${ }^{117}$.

Atendendo a que alguns destes vocábulos perderam definitivamente o sentido colectivo, sendo embora mais comuns no plural, é possível encontrar formas de singular e com a terminação de masculino: «... o qual vos deu por morada tam nobre elamento, asy que tenhades agoas doçes e salgadas...) (Crónica da Ordem dos Frades Menores, do séc. XIII, I, p. 228); o mesmo se passou com intestino (este, mais comum no plural): «depois chegou com a maão aos stemtinos» (Séc. XV: Crónica da Ordem dos Frades Menores, I, p. 289118).

Premia, forma feminina comum na época medieval, tem a mesma origem («et da boa çima que vyo que $11 \mathrm{j}$ Deus quiso dar en premia de seu traballamento» 889. 13119), tal como sarilho de "*sericula"120. $\underline{\text { Fruta }}$ e lenha, entre outros exemplos, mantiveram o sentido de colectivo.

6 Artur Bivar, no Dicionário Geral e Analógico da Língua Portuguesa. 3 vols. (Porto, Edições Ouro Lda. 1948-1958 e 1951) refere que, ainda hoje, na província de Trásos- -Montes legumia designa "os legumes, os produtos da horta”, mantendo, portanto, o sentido colectivo. Derivam do plural neutro acta, ani mal ha, arma (que o Latim usava só no plural), claustra (castra e crasta), folha, fruta, ferramenta, lenha, ova, vestimenta, etc.

116 Citado por Viterbo: 207, s. u. "acta".

117 «Antigamente, diziam em latim ecclesiaria. para significar o igrejairo, ou todas as igrejas, de que se falava». Viterbo: 327 , s. u. "igrejairo".

1 ^ Ambas as citações provêm da edição de J. J. Nunes (Coimbra ,Imprensa da Universidade 1918) vol. 1.

1 ^ Citação extraída de Ramón Lorenzo, 1977, s. u. "premja".

120 Segundo o Romanisches Etymologisches Wörterbuch, $4^{\circ}$ ed. (Heidelberg, Carl Winter Universität Verlag 1968) de Meyer-Lübke. Também Antenor Nascentes, 1955: 715 dá a mesma proveniência.

\section{Faculdade de Letras | Universidade de Coimbra}




\section{Considerações sobre a categoria gramatical de género}

3.8. Vocábulos de género variável

São inúmeros os vocábulos do Português arcaico com género variável $^{121}$; mas iremos deter-nos nos mais significativos:

$\underline{\text { Arvore }<~ " a r b o r, ~-i s ", ~ g e r a l m e n t e ~ f e m i n i n a ~ e m ~ L a t i m, ~ d e p o i s ~}$ de um período de hesitação quanto ao género fixa-se no feminino etimológico, sendo já assim detectável no séc. $X$ : «suas casas et suas amores» ${ }^{122}{ }^{*} ;$ e de novo no séc. XIII, no Foro Real, mantendo depois esse género. Não obstante, um texto do séc. XVI regista o masculino e a hesitação: «por toda a terra vereys muy poucos arvores» e «eu vy na cidade de Recalem hu arvore que debaixo dela...» (Crónica dos Reis de Bisnaga ${ }^{122}$ ).

Cárcer < "career, -eris", masculino, pode apresentar um ou outro género: «o fezera porende tan tosf en un career deitar» \{Cantigas de Santa Maria, 5. 57124) e «log'abriu / a career mui teevrosa» \{Ibidem, 106. $\left.57^{125}\right)$.

$\underline{\text { Fim }<~ “ f i n i s, ~-i s ", ~ a m b i ́ g u o ~ e m ~ L a t i m ~}{ }^{126}$, é largamente documentado com os dois géneros: «Par San Martin, / maestre, mui prefe a uossa fin" $"$ (Ibidem, 17. 71127) e «A qual pusemos no fim» \{Livro da Montaria, "Prólogo", $.3,30^{128}$ ). No Livro da Vertuosa Benfeytoria (séc. XV) ainda se regista o feminino: «fym postumeyra» (Livro VI, cap. X, 1. 21, p. 344) e «que a sua fym é departida em tres maneiras» (Livro III, cap. XIV, 1. 13, p. 229). Só posteriormente o masculino se fixará.

171 Para além dos referidos neste artigo: "çaiom" 'ocasião', cegonha, esfinge,

"mciiom", "mó" (ambíguo no Orto do Esposo, 347. 32), nariz, etc.

i ??

Ramón Lorenzo, 1977: 177, s. u. "aruor, aruol", de Portugalio Monumenta

Historica. "Diplomata et chartee ", 88.

por David Lopes (Lisboa, Imprensa Nacional 1897) 81.

${ }^{122}$ Crónica dos Reis de Bisnaga. Manuscript inédito do século XVI publicado

124 Walter Mettmann, 1959: 16.

$125 \quad$ Idem. 1961: 17.

'2^ .1. P. Machado, 1987: s. u. "fim" diz a respeito desta palavra: «este voc[ábulo] lat[ino] documenta-se nos dois géneros, se bem que o masculino pareça ser mais antfigo]; o feminino deve-se à analogia com outras palavras de tema em -i-, entre as quais predomina este género».

122 W. Mettmann, 1959: 54.

128 Feito por D. João I, Rei de Portugal, conforme o manuscrito 4352 da Biblioteca Nacional de Lisboa, [editado] por Francisco Maria Esteves Pereira (Lisboa, Academia das Ciências 1918). 


\section{Maria Carmen de Frias e Gouveia}

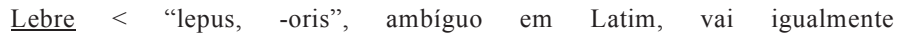
conhecer hesitação no uso do género, que se prolongará até ao século XVI.

Mármore < "marmor, -oris", neutro, esperar-se-ia que passasse a masculino, como hoje acontece. No entanto, encontra-se a forma feminina no século XV — «Este templo era feito de marmores mui alvas» 129 - possivelmente por associação com "pedra". Rosa V. Mattos e Silva130 dá-o igualmente como feminino.

Queixume, por sua vez, cedo conhece também ambos os géneros, que podem coexistir no mesmo texto. Disso é exemplo o Documento 2, de 1262, recolhido e transcrito por Clarinda Maia: «de todos estes

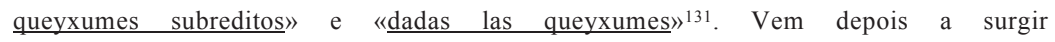
uma forma analógica a realçar o género feminino ${ }^{132}$.

Por último, $\underline{\text { Sangue }}<$ "sanguis, -inis", masculino, documentase como tal no séc. XIV («o emiigo deitou comigo tã muitas pulgas que mi çugavã o ssangui» $\left.{ }^{133}\right)$; mas encontra-se também o feminino no Livro de Linhagens do Conde D. Pedro: «As chagas erã muytas, de que se vertia

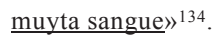

Só mais tarde e, em vários casos, muito posteriormente ao século XVI, se começará a fixar o género definitivo, geralmente o etimológico.

3.9. Género etimológico alterado pela terminação (e influência desta na atribuição do género)

Devido à terminação, femininos como "echo", "ficu-", "porticu-", etc. tornarain-se masculinos. Pelo mesmo motivo, houve masculinos ou neutros que passaram a femininos no Português arcaico. É o caso

199 Ludolfo Cartusiano, $O$ livro da Vita Christi em lingoagem português (Ed. facsimilar. Ministério de Educação e Cultura - Casa de Rui Barbosa [1957]). Cap. Il, p. 47, 111, 1.3.

$130 \quad$ Rosa V. de Mattos e Silva, 1989: 115.

131 Clarinda Maia, 1986:43.

132 «...te fazemos senhora queixuma do que os nossos olhos oje nos mostraraõ» Fernão Mendes Pinto, Peregrinação. Nova edição conforme a de 1614 . Preparada e organizada por A. J. da Costa Pimpão e César Pegado (Porto 1944) cap. 141, vol. IV, p. 151.

133 Citado por J. J. Nunes, Revista Lusitana, XXVII, 68-69.

134 É feminino ainda em 1507. Cf. O Manuscrito Valentim Fernandes oferecido... por Joaquim Bensaúde (Lisboa, 1940) 22.

Faculdade de Letras | Universidade de Coimbra 


\section{Considerações sobre a categoria gramatical de género}

de “clima" (n.), “cometa, -æ" (m.), “diadema, -atis" (n.), "phantasma, atis" (n.), "planetae, -arum" (m.), "propheta" (m.) ou "schisma" (n.), etc.

Vejamos os seguintes empregos: «...pareceo aquella cidade humma muy grande cometa feita à maneira de dragão» (Zurara, Crónica de D. Pedro de Meneses $\left.{ }^{133}\right)$, «inconvenientes, que nos tempos das Cis$\underline{\text { mas }}$ se podiam seguir avendo mais d'hu Papa» (Rui de Pina, Crónica de D. João //, cap. 26 $6^{136}$ ) e «a profeta Dauit» (Primeyra Partida, VIII, $265^{137}$ ); contudo, nos séculos seguintes, o masculino - que vemos em «esto he scripto por o propheta» \{Livro da Vertuosa Benfeytoria, I, cap. $\mathrm{XV}, 1.5, \mathrm{p} .45)$ - passa a ser mais frequente.

Outros casos há em que foi a terminação que se acomodou ao género que se veio a fixar, como ocorre em vocábulos que designam pedras preciosas: "amethystus" e "sapphirus" eram femininos, tal como "agatha"; "smaragdus", geralmente do género masculino, passou ao feminino - hoje cornum a todas as formas citadas. No entanto, todas elas parecem acusar oscilação de género, conforme se lhes apunha, por exemplo, "lapis"(masc.) ou "gemma"(fem.): «duas sortellias e iij lapides saphiros» ${ }^{138} \mathrm{e}$ «hua obra asy come de pedra çafíra» ${ }^{139}$.

3.10. Expressão do género por processos derivacionais

3.10.1. Femininos formados por derivação

$\mathrm{Na}$ maior parte dos casos, trata-se de herança do Latim: «o Cond'e a Condessa lhe disseron...» \{Cantigas de Santa Maria, 5. 83 ${ }^{140}$ ); ${ }^{*} 117118^{* * * * * * * * * *}$

135 Maria Teresa Brocardo, Crónica do Conde D. Pedro de Meneses de Gomes Eanes de Zurara. Edição e estudo (Lisboa, Fundação Calouste Gulbenkian e Junta Nacional de Investigação Científica e Tecnológica 1997).

1

Croniqua delRey Dom Joham II. Nova edição com prefácio e notas de Alberto Martins de Carvalho (Coimbra, Atlântida 1950).

117

Edição de José de Azevedo Ferreira, 204. No mesmo texto, como se refere na p. XLI, patriarcha parece surgir com ambos os géneros.

118

J. P. Machado, O testamento de D. Mafalda (1256). In: Revista de Portugal, Série A - Língua Portuguesa, XXI, fase. 145, Maio 1956, p. 157-164. Citação da p. 159.

$11 \mathrm{Q}$

Cf. Ineditos portugueses dos séculos XIV e XV, que ou forão compostos originalmente, ou traduzidos de varias linguas, por Monges Cistercienses deste Reino. Ordenada e copiada fielmente dos manuscritos do Mosteiro de Alcobaça por Frei Fortunato de S. Boaventura, monge do próprio Mosteiro. Coimbra, 1929, II, p. 123. A este propósito, cf. o que foi dito supra acerca de mármore.

Walter Mettmann, 1959: 17. A forma parece provir do Latim tardio "comitissa" 


\section{Maria Carmen de Frias e Gouveia}

«se podi'aver ontr'eles algua tal deoessa...» 141 \{Ibidem, 335. 80); como título eclesiástico, surge «padressa» (Orto do Esposo, 176, 27*142).

Pelo que respeita as palavras terminadas em -or (cf. Ponto 3.5), a par do feminino por acrescentamento de um $\wedge$ a, criou-se a terminação $z$ eirá, de que há abonações desde o séc. XIII: «parayso, que é vida durade ira» 143; «ca de salvar os seus senpre é mui sabedeira» (Cantigas de Santa Maria, 137. 53144); «molher cantadeyra» (Orto do Esposo, 161, $\left.12^{145}\right)$ ou «Lyanor Peixota proccuradeira» ${ }^{146}$.

E possível ainda encontrar o feminino etimológico $\underline{\text {-driz }}$ (< “-trix, -icis”): «Esta é como Santa maria ajudou a Emperadriz de Roma...» (Cantigas de Santa Maria, 5. I ${ }^{147}$ ); «Esta moller... era tan peccadriz...» \{Ibidem, 272.16148*).

Ainda por derivação há o feminino prioressa: «foi contar est'aas donas des $\mathrm{i}$ aa prioressa»" ${ }^{49}$ \{Cantigas de Santa Maria, 222. 37), forma que Clarinda Maia regista ainda em documento do século $\mathrm{XV}^{150}$.

Em suma: os adjectivos (e alguns substantivos) em -or, embora frequentemente uniformes, conheciam no Português arcaico quatro tipos

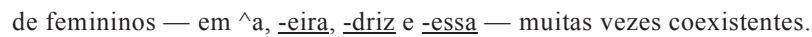

^ Forma que nos vem através do Francês.

142 Indicação extraída de Bertil Maler: 117

I2 W. Mettmann, 1961: 285. É possível que se trate de uma forma analógica da terminação eiro, de que as Cantigas de Santa Maria apresentam vários exemplos:

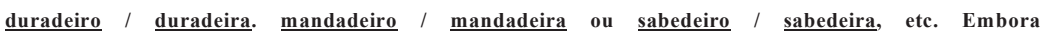
aparecida mais tardíamente, a terminação -eira passou a alternar com -ora, mantendo (até hoje) conotação mais popular. No entanto, Fernão de Oliveira (cap. XLI) no séc. XVI, esclarece: «dizemos homem pescador e mulher pescadeira».

144 W. Mettmann, 1961: 106.

^ Bertil Maler: 58, s. u. "cantadeyro".

^ Citação extraída de Maria José Azevedo Santos e Maria Teresa Veloso, Pergaminhos do Instituto de Paleografia (Séculos XII-XVIII). Coimbra, 1983, p. 25, doc. 12, de 1472. Coexistiu com a forma (fern.) procurador. Cf. Ibidem, p. 28, doc. de 1479: «a dieta senhora... como sua procurador».

147 Walter Mettmann, 1959: 15.

148 Idem, 1964:. 272. Já na p. 118 se encontra: «assi como faz moller mui pecadriz" (298. 50). Nas próprias Cantigas de Santa Maria esta forma coexiste com a invariável, em «jr: «.. .hua moller peccador» (237.2).

${ }^{49}$ A par deste, existe a forma de feminino priola: «Abadess'avernos tal / e priofe tesoureira» (Cantigas de Santa Maria, 94. 86. W. Mettmann, 1959: 270).

Clarinda Maia, 1986: 658.

\section{Faculdade de Letras 1 Universidade de Coimbra}




\section{Considerações sobre a categoria gramatical de género}

3.10.2. Palavras derivadas com o mesmo sentido e géneros diferentes

Esta é uma situação bastante frequente no Portugués arcaico: $\underline{\text { aforação / aforamento, }}$ ardideza / ardimento, $\underline{\text { correcção / corregimento, }}$ delonga / delongamento, perdoação ou perdoança / perdoamento, vendição / vendimento, etc., entre muitíssimos exemplos que se poderiam mencionar.

Vejam-se as seguintes abonações: «nem jamais homem non havia sabor de matar se por defendimento do seu corpo nom fosse» (Demanda do Santo Graal 151), ao lado de «he de defensom de nossa franqueza e de nossos corpos» ( Vida e Feitos de .Júlio César, I, 8, pgf. 40, $9152 *)$ e de «em outro dia britarom-lhe as portas sem defesa» (Ibidem, II, 4, pgf. 33, 6); ou ainda: «...o Senhor o acreçentasse e estendesse seu real estado com perlongamento de bem aventurados dias» (Fernão Lopes, Crónica de D. Pedro, cap. 3, p. 18152) a par de «avendo ja xiiij anos que duraua a perlomgança deste negoçio» (Crónicas dos Sete Primeiros Reis de Portugal $\left.{ }^{154}\right)$.

Coexistiram, portanto, várias formas, com terminações que tinham origem nas latinas: -MENTU (aumento, perdimiento, etc.), TIONE (perdição, destruição...), e ainda -ANTIA (olvidança), -ITIA (ardideza) ou -URA ( $\underline{\text { ardura }}, \underline{\text { calçadura) }}$ - sendo difícil estabelecer qual das formas é a mais antiga. De qualquer modo, parece-nos que muitas das formas em -mento cederam o lugar a outras terminações.

É também a conclusão a que chega Donald Lenfest ${ }^{155}$, após uma análise da derivação dos vários substantivos abstractos na Primera Crónica General. «A pesar de que muestran claramente su relación etimológica con las correspondientes formas verbales, rompimiento e perdimiento desaparecen porque son fonéticamente menos económicas que los cultismos ruptura y perdición.» (p. 317) e «También se ven casos en

\footnotetext{
^ Demanda do Santo Graal. Edição de Joseph-Maria Piel (atrás citada).
}

Citação extraída de Maria Helena Mira Mateus, "Glossário da Vida e Feitos de Júlio César: Letra D" in Boletim de Filologia, tomo XXVI (Lisboa, Instituto Nacional de Investigação Científica - Centro de Linguística da Universidade de Lisboa 1981) 277.

$1 \mathrm{SS}$

Fernão Lopes, Crónica do Senhor rei Dom Pedro, oitavo Rei destes Regnos

(Porto, Livraria Civilização Editora 1986).

Edição crítica de Carlos da Silva Tarouca, S. J. Lisboa, 1952, vol. 1, Crónica de D. Afonso III, cap. III, p. 252, 1.21.

Donald Lenfest, "La derivación de sustantivos abstractos en la «Primera crónica general»" in La lengua y la literatura en tiempos de Alfonso X Actas del Congreso Internacional. Murcia, 5-10 de marzo 1984 (Murcia, Departamento de Literaturas Románicas, Facultad de Letras, Universidad de Murcia 1985) 305-318. 


\section{Maria Carmen de Frias e Gouveia}

los cuales entra un cultismo, por ejemplo, defendimiento desaparece frente a defensa, palabra usada ya en el bajo latín» (p. 309). Parece, com efeito, que são mais vulneráveis «los sustantivos abstractos a base de verbos [como avondamento, defendimento, perdimento, entre muitos outros, que competiam com outras formas], principalmente porque esos han tenido que competir con formas postverbales» (p. 317).

3.10.3. Aumentativos e diminutivos que implicam mudança de género

A terminação -ONE empregava-se já no Latim com sentido de aumentativo, que continua a ter na época medieval. Até mesmo perdigão ${ }^{156}$ (< "perdicone-") é entendido como o aumentativo de perdiz $(<$ "perdix, icis"), possivelmente devido ao maior tamanho do macho desta ave.

Por exemplo, encontram-se registadas, não só albarda mas o seu aumentativo albardão: «leixad'or'o selegon / e tornad'ao albardon» (Cantigas d'escarnho e de mal dizer, 262. 3); e citolon (< “cithara"): «e fende farei / o citolon na cabeça quebrar» (Ibidem, 218. 31); e ainda espadarron (de “espada"): «... / e sobarcad'un vellf espadarron» (Ibidem, 57. 15) 157 158. Não só porque se trata de composições de escárnio e de maldizer, mas também devido ao contexto onde se inserem, facilmente se depreende que estes aumentativos são sempre usados em tom jocoso ou em sentido pejorativo.

Menos frequentes no material que recolhemos parecem ser os diminutivos que impliquem uma alteração do género da palavra de que derivam. No entanto, J. Pedro Machado regista, de uma abonação de 1364 ${ }^{158}$, sachóla como diminutivo de sacho.

3.11. Adjectivos do Português $\operatorname{arcaico}^{159}$ (não referidos anteriormente)

No Latim coloquial tardio, havia tendência a regularizar os paradigmas, estendendo o tipo flexional "-us, -a, -um", como se

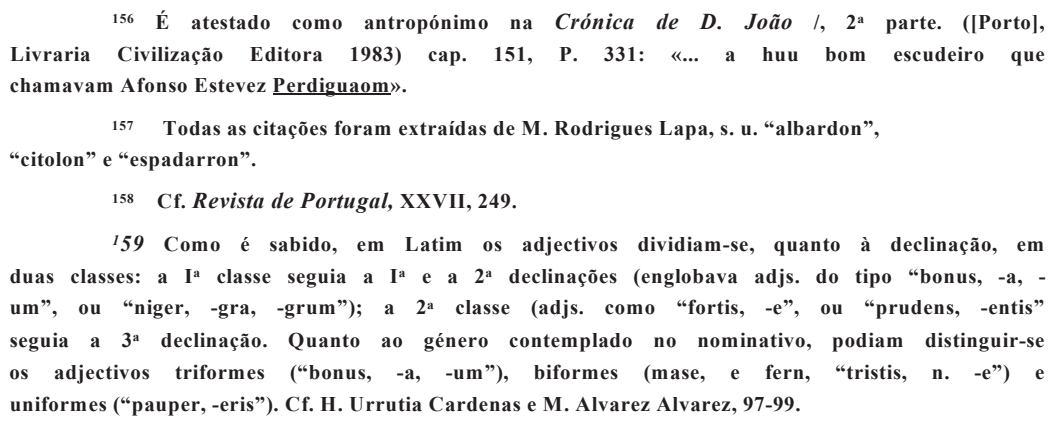




\section{Considerações sobre a categoria gramatical de género}

depreende do Appendix Probi: «tristis non tristus», ou "pauper mulier non paupera mulier» ${ }^{160}$. No entanto, alguns adjectivos que eram regulares deixaram de o ser.

Com o desaparecimento do neutro e na evolução para o Português arcaico, vamos encontrar, como biformes, adjectivos que que eram triformes em Latim; foi o caso de "bonus, -a, -um" > 'bõo / bõa', "malus, -a, -um" > 'mao /maa', "securus, -a, -um" > 'seguro / segura', etc. Outros, primitivamente triformes, tornaram-se uniformes: como "celeber, -bra, brum" > "célebre'. Por sua vez, os biformes latinos ficam uniformes: "facilis, -e" > 'fácil', "leuis, -e" > 'leve', "utilis, -e" > 'útil', etc., mantendo-se os uniformes como tal: "atrox, -cis" > "atroz', "pauper, -eris" > 'pobre', "stabilis, -e" > 'estável', etc.

Caso mais curioso é o daqueles adjectivos como, entre outros, "communis, -e", "rudis, -e" que, a par dos adjectivos uniformes deles resultantes, continuavam biformes (mase. / fern.), fruto da confusão já existente em Latim entre os adjectivos da $2^{\text {a }}$ classe e os da $\mathrm{I}^{\mathrm{a}}$. De um interesse muito especial, tratar-se-á deste assunto noutro artigo ${ }^{161}$, para então lhe ser dado o pormenor que merece. Consequentemente, sobre este assunto apresentam-se agora só duas citações, em contraste: «Podes quanto quiseres / fazer, mas anfeu morrerei, vilão, falsso, rudo» (Cantigas de Santa Maria, 237. 52162) e em Luís de Camões «frauta ruda»" ${ }^{16 \wedge}$. Tal situação não se verifica apenas no século XVI, mas prolonga-se para além dele.

Além destas abonações, encontramos outros adjectivos que mantêm a sua condição biforme ao longo de todo o período de que estamos a tratar: «eu sõo mui covarda de por nulla ren rogar-te» (Cantigas de Santa Maria, 55. 47164); «hua dona ... mui fazedor d'alg'e de todo mal quita» (Ibidem, 9. 12) e «pois de vison foi quito» (Ibidem, 15. 119), a par de «era de bõa vid'e quite de toda sandece» (Ibidem, 208. 9) ${ }^{165}$. Só posteriormente aos séculos XVI-XVII se fixam as formas actuais. Relativa-

160 çf $\left[_{\mathrm{vo}}[]_{\mathrm{e}}\right.$ Castro, Curso de história da língua portuguesa (Universidade Aberta, 39, 1991)91-93.

161 Cf. a nota inicial deste artigo, marcada com *, na qual se faz menção ao que se lhe seguirá.

$16 \wedge$ Walter Mettmann, 1961: 342.

${ }^{16 \wedge}$ Luís de Camões, Os Lusiadas, I, 5.

${ }^{164}$ W. Mettmann, 1959: 158

16^ J. Huber, na Gramática do português antigo (Lisboa, Fundação Calouste Gulbenkian 1986) aponta ainda as formas "contento" e "contenta", "fermo" e "ferma", como comuns em Português antigo. 
mente a outros adjectivos, seguem o Latim de um modo geral. Assim, encontramos formas como "bõo" e "bõa", "fremoso" e "fremosa", juntando-se-lhes os participios passados "culpado" e "culpada", "mesurado" e "mesurada", etc.

\subsection{Diferença semântica dada pelo género}

Apresentava o Português arcaico, tal como o Latim, alguns pares de palavras em que a diferença de género implicava, simultaneamente, uma distinção semântica. Para além da evidente diferenciação de sexo, de que já se falou anteriormente, encontramos o género gramatical como modo de evidenciar o sentido diferente dessas palavras.

Em Latim, por exemplo, estão nesta situação (embora na altura fosse um recurso menos produtivo), entre outros, os seguintes pares de vocábulos: “ficus, -i” (f.) 'figueira' / “ficus, -i” (m.) 'hemorróida(s)'; "lixa, -æ" (f.) 'água quente para a decoada da lixívia' / "lixa, -æ” (m.) 'servente do exército'; "lucta, -æ" (f.) 'luta' / "luctus, -us" (m.) 'dor', 'mágoa', para além de certos pares de palavras (como "lignum" / "ligna") de outra proveniência.

Segundo Joseph Huber ${ }^{166}$, a existência em Português antigo de formas duplas (folho / folha, fruito / fruita) levou a criar, para muitos femininos (em -a), um masculino (em -o): como 'migalho'. E o inverso também ocorreu.

Consideremos, agora, um exemplo entre muitos do Português arcaico, em que as formas duplas, ambas provenientes do neutro latino "debitum, -i", traduzem uma diferença semântica: divido (m.) 'promessa,

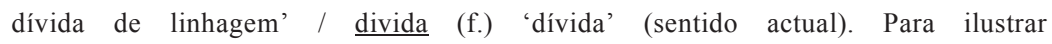
estes dois empregos, vejam-se as transcrições: (m.) "comprio o divido natural»167 e "nom embargando o dito divedo de linhagem» 168; (f.) "XII soldos para pagar sa divida $"{ }^{169}$.

Este tipo de formas irá proliferar largamente na língua portuguesa ao longo da sua evolução ${ }^{170}$, e nem sempre da melhor forma. Por

166 J. Huber, 168.

167 Citação colhida em Rosa V. de Mattos e Silva, 1989: 126.

168 Fernão Lopes, Crónica de D. João I. Cap. CXC, p. 417,1. 2.

169 Cf. Rosa V. de Mattos e Silva, Idem. Já em 1214, no Testamento de D. Afonso

//, aparece a forma deuidas com o mesmo sentido.

170 Encontram-se inúmeros exemplos de formas duplas no Português actual em

Albrecht Pabst,

im Portugiesischen (Bonn, Rheinische Friedrich Wilhelms

Universität 1961).

Faculdade de Letras I Universidade de Coimbra 


\section{Considerações sobre a categoria gramatical de genero}

isso escrevia Fernão de Oliveira: «de baçio dizemos baçia e diverso genero: $\tau$ de çepo çepa. $\tau$ de çesto çesta. $\tau$ de bãco bãca. mas não de mesa, meso: ne de casa caso....» ${ }^{171}$.

\subsection{Palavras em -ão}

Os substantivos e adjectivos em zäo derivam normalmente das terminações latinas "-anu" ("hortulanu-" / "hortulana-"), "-ane" ("cane-") e "-one" ("abigone-"), e podem ter no Português medieval vários tipos de femininos: $\underline{- \text { ona, }}$

\section{-õa, $\underline{\text {-oa, }}$ - -ana $\mathrm{e}^{\wedge} \tilde{\mathrm{a}}^{172}$.}

Vejamos algumas abonações, como as seguintes: «aleymãa» (doc. de 1328) e «alemanna» 172; «Oi noutro dia en queixar / üas coteifas e outras cochõas» (Cantigas d'escarnho e de mal dizer, 238. 9174); "quen trobar non dever / por ricas donas nen por infançoas» ÇIbidem, 238. 7175); e «andando senpre de noite, come sse fosse ladroa» 176 (Cantigas de Santa Maria, 55. 23 ${ }^{177}$ ).

É difícil saber qual o tipo de feminino mais antigo, inclusivamente por causa das variantes gráficas, e por haver terminações de diferente proveniência. No entanto, Dulce de Faria parece crer que será -oa, que, segundo a Autora, passa a Jí ao longo do século $X^{178}$. Porém, da análise do material recolhido não se obtiveram dados suficientemente seguros para traçar essa cronologia.

Rosa Mattos e Silva afirma que as grafias do tipo irmãã. ermitãã, sãã, vãã, etc. são indicadoras de que, pelo menos na escrita, «a fusão das nasais idênticas não está representada nesses nomes» 179 *

\section{*7' Eernão de Oliveira, cap. XLI.}

As formas com síncope do -n- são o resultado normal na evolução do galegoportuguês. $O$ problema põe-se em saber, nos casos em que a nasal intervocálica existe, se se trata de influência castelhana, ou de um modo de representar a ressonância nasal, ou se é uma grafia latinizante. Na maior parte dos casos, é provável que seja um caso de grafia.

177 Walter Mettmann, 1972: 14, onde se indicam várias ocorrências.

${ }^{\wedge 74}$ Citação extraída de M. Rodrigues Lapa, s. u. "cochõa".

^Idem, s. u. "infançoa".

$$
\hat{\mathrm{i}} \boldsymbol{\eta} \boldsymbol{I} \varepsilon
$$

A forma actual "ladra", que parece ser posterior, deriva directamente de "ladro"< "ladro". J. P. Machado documenta-a no see. XVI.

177 W. Mettmann, 1959: 157.

178 Dulce de Faria Paiva, 43.

$\wedge^{79} \mathrm{Cf}$. O Português arcaico. Morfologia e sintaxe, 20. 


\subsection{Os alomorfos de género}

Consideremos também um aspecto de alomorfia que consiste na alternância vocálica entre a forma do masculino e a forma do feminino no que respeita à vogal tónica. Esse alomorfo é uma marca redundante, na medida em que se acrescenta ao morfema $\wedge$ a, marca mais geral da expressão do feminino.

Rosa Virgínia de Mattos e Silva estudou os vocábulos deleitoso / deleitosa / deleitosos / deleitosas; espantoso / espantosa / espantosos / espantosas; fremoso / fremosa / fremosos / fremosas; glorioso / gloriosa / gloriosos / gloriosas; homildoso / homildosa / homildosos / homildosas; maravilhoso / maravilhosa / maravilhosos / maravilhosas; e religioso / religiosa / maravilhosos /maravilhosas; e concluiu que em todos estes casos a metafonia180 se dera na forma feminina. Quanto a novo / nova / novos / novas, esse fenómeno deu-se no masculino.

No entanto, dado que a ortografia não nos é esclarecedora quanto a este aspecto, no estudo que fizemos não foi possível chegar a uma conclusão sobre o facto de haver ou não alternância neste tipo de vocábulos.

De qualquer modo, ao longo do século XVI verifica-se uma evolução muito significativa no que respeita a "formosa" (na sua oposição vocálica em relação à forma de masculino), atestada pelos gramáticos da época $^{181}$. Aproximávamo-nos já do Português actual.

\subsection{Observações sobre alguns vocábulos}

Escolhemos para esta alínea os casos de avó, parva, só e viúva, palavras que apresentavam no Português arcaico uma forma feminina mais próxima do Latim: avoa, parvoa, soa e viuvoa.

100 Entende-se por Metafonia a alteração de timbre da vogal da sílaba tónica de um vocábulo, originada pela vogal final. Conforme se trate da vogal -a ou -u, vai ocasionar-se, respectivamente, uma abertura ou um fechamento dessa vogal tónica. Por exemplo, em "formõsu-" e "formosa-", a metafonia parece ter ocorrido na forma do feminino motivada pela vogal final ^a, criando uma alternância vocálica com a forma do masculino, que manteve o timbre fechado etimológico. Pelo contrário, em "nõuu-" e "nõua-" a metafonia deu-se no masculino, que, por influência do hi, passou a ter um timbre mais fechado, alternando com o resto da flexão.

101 Veja-se em pormenor este assunto no artigo dedicado à categoria gramatical de género, na sua evolução dentro da língua portuguesa (a publicar). 


\section{Considerações sobre a categoria gramatical de genero}

$\underline{\text { A voa }}<$ "auola" < "auiõla-", tinha como masculino $\underline{\text { auoo }}^{182}{ }^{183}$. É

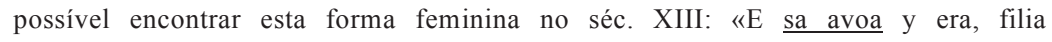
del Rei d'Ingraterra» \{Cantigas de Santa Maria, 221. 20182). Anterior-

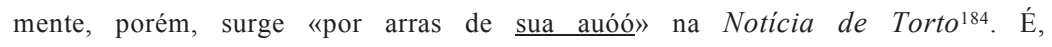
no entanto, difícil saber se a abertura da vogal já funcionaria (ou não) como alomorfo de género. A este respeito, escreveu Rosa Virgínia de Mattos e Silva: «Tal facto só poderia ser percebido em documentos escritos em verso. Como entre 1350 e 1460 é rara a documentação poética em português, não se pode fundamentar o facto de nessa época a alternância vocálica já ser utilizada como um marcador mórfico para distinguir o masculino do feminino em avoo»" ${ }^{185}$.

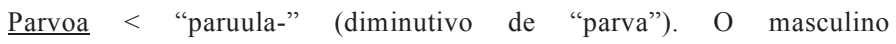
$\underline{\text { parvoo }}<$ "paruülu-" (diminutivo de "paruus") também se encontra documentado nos sécs. XÍV e XV186.

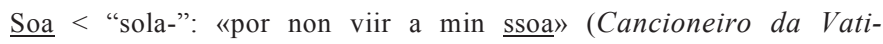
cana, 992187); 4 Demanda do Santo Graal apresenta, alternando no mesmo texto, sooa e soo ${ }^{188}$ : «acharon ua donzela que ia soo em uu palafrém» e «achou i uua donzela ssoa; siia sooa....».

$\underline{\text { Viu voa }<~ " * u i d u u a " ~(f o r m a ~ c o m ~ d e s d o b r a m e n t o ~ o u ~ c o m ~ e p e ̂ n-~}$ tese de -u-) < "uidua-". Também esta forma de feminino se documenta desde cedo: «Se algua molher for uiuuoa....» ${ }^{189}$.

Embora fixados após o séc. XVI os femininos actuais, chegaram até ao nosso século algumas destas formas na linguagem popular.

Uma última referência para os nomes que designam animais.

Enquanto que em Latim alguns desses nomes tinham já uma forma para o masculino e outra para o feminino ("taurus, -i" / "taura, -æ"; "palumbus, -i" / "palumba, -æ", etc.), muitos outros nomes (os chamados

182 Em galego-português, e à semelhança do que ocorreu com a nasal alveolar intervocálica (-n-), também a lateral ápico-alveolar (-1-) se perdeu em idêntico contexto.

183 Walter Mettmann, 1961: 302.

${ }^{\wedge 4}$ Conforme a edição de L. F. Lindley Cintra, in Boletim de Filologia, vol.

XXXI, 1991,37-41.

185 Rosa V. de Mattos e Silva, 1989: 120.

186 Fernão Lopes, Crónica de D. João /. Cap. LXXV, 146.

I82 Cancioneiro Português da Vaticana. Edição crítica, restituída sobre o texto diplomático de Halle, acompanhada de um Glossário e de uma Introdução... por Teófilo Braga (Lisboa 1878).

^88 Demanda do Santo Graal (atrás citado).

189 Cf. Ramón Lorenzo, 1977, s. u. “viuua, veuda’ 


\section{Maria Carmen de Frias e Gouveia}

epicenos) dispunham só de uma forma para ambos os sexos: "bos, bouis”, 'boi' e 'vaca'; “canis, -is”, ‘cão' e 'cadela'; “sus, suis”, 'porco' e 'porca', etc.

O Português arcaico, para o caso dos animais com que mais diariamente se tinha contacto, sentiu necessidade de procurar e utilizar formas femininas, na sua maior parte originárias do próprio Latim: vaca <

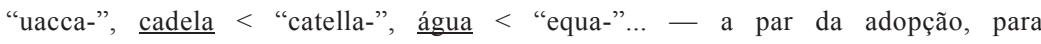
o masculino, da forma do Latim tardio "caballu-", entre outras. Por sua vez, de alguns desses femininos surgem masculinos analógicos, como $\underline{\text { cadelo }}$ < “catellu-", diminutivo de 'cão': «des que os cadelinhos...» \{Livro da Montaria, II, cap. XII, 66, 15 $\left.{ }^{190}\right)$. Exemplo de um feminino analógico parece ser também a forma gafanhota, que surge em fins do século XIV, no Orto do Esposo (117.30191). Parece mesmo que, na época, era menor o recurso ao masculino genérico ${ }^{192}$.

As Cantigas de Santa Maria documentam a forma passarinha' ${ }^{193}$ (de "passer, -eris", 'pardal') com o sentido de pássaro em geral: «oyu hua passarinna cantar...» (Ibidem, 103 . 23194*); Viterbo regista a forma pássara com o sentido de 'perdiz': «Com foro de um par de passaras» (Prazo de S. Pedro das Águias, de 1444193).

\section{Conclusões}

Independentemente da complexidade que envolve a categoria de género, a que nos referimos brevemente no início deste trabalho ${ }^{196}$, ao

199 Feito por D. João I, Rei de Portugal, conforme o manuscrito 4352 da B. N. de Lisboa (atrás citado).

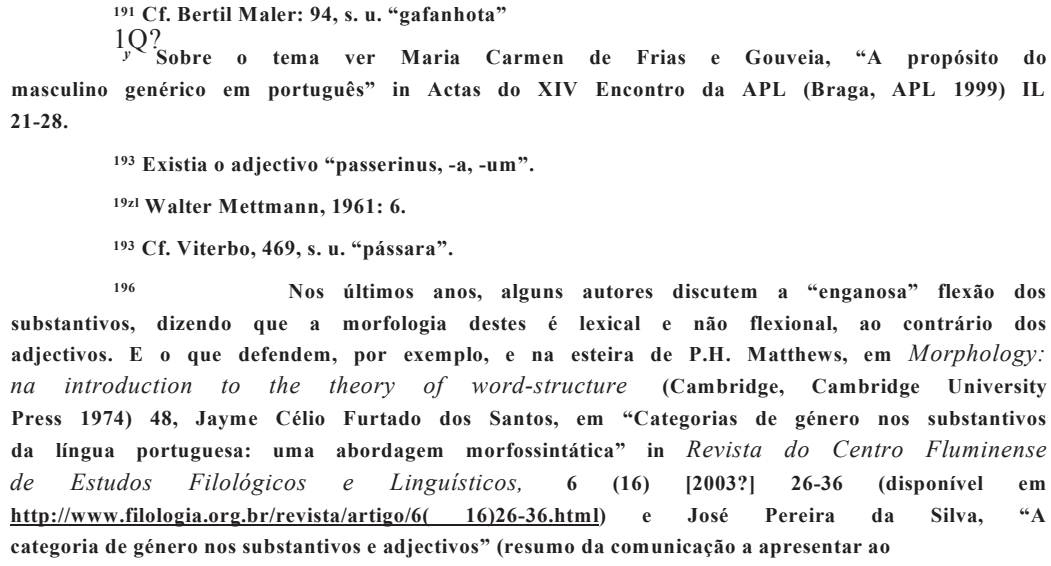


longo do estudo feito sobre esta primeira fase da língua portuguesa, verificou-se que o seu uso estava sujeito a muitas hesitações; outras vezes, formas redundantes de género coexistiam no mesmo texto. Esta situação denunciava que uma evolução ia ocorrer, uma vez que, como se sabe, a coexistência de duas formas numa dada época leva ao abandono gradual de uma em favor de outra (Cf. 3.1. e 3.8., acerca da mudança ocorrida nas palavras invariáveis).

Nalguns casos, seguia-se o género etimológico herdado do Latim. Noutros, a par do uso de uma forma como invariável (p. ex. infante), anuncia-se já a preocupação em criar, analógicamente, formas para expressar o feminino. O processo mais produtivo foi, ao longo da época em apreço, o acrescentamento de -a (3.2. a 3.6.), o que se verifica cedo na Língua (século XIII). Também a derivação teve um papel importante na época (3.10.), embora muitas das formas então utilizadas pertençam hoje à linguagem popular (pescadeira, etc.). Através dos exemplos, verificou-se que a inerência do género é uma característica tanto do substantivo primitivo como do derivado, ocorrendo que determinados sufixos derivacionais têm função de verdadeiros atribuidores de género, obrigando alguns a modificar o género do substantivo que daí deriva ${ }^{197}$.

Mais tardíamente utilizado foi o processo morfo-fonológico da alternância vocálica (3.14.), que parece ter-se afirmado definitivamente só ao longo do século XVI.

Em qualquer dos casos, porém, como foi referido ao analisar cada tipo estudado, a fixação definitiva será posterior ao século XVI (altura em que começam a surgir as gramáticas da Língua). Mas ainda nos nossos dias é possível encontrar hesitações de género, havendo, inclusivamente, algumas alterações em curso, mesmo na língua culta ${ }^{198}$.

I Congresso Internacional de Estudos Filológicos e Linguísticos, a ter lugar no Rio de Janeiro, entre 23 e 27 de Agosto de 2004, disponível on-line). Na Moderna gramática portuguesa, 37 a ed. (Rio de Janeiro, Editora Lucerna, 2001) 132-133, Evanildo Bechara refere que a diferença de sexo nos animados se revela ou pela mudança de sufixo ou pela heteronímia, sendo sempre palavras diferentes em qualquer dos casos, o que não difere muito deste entendimento.

197 A este propósito consulte-se M. Nazaré de Carvalho Laroca, Manual de morfologia do português (Campinas, Pontes, Juiz de Fora, UFJF 1994). Exemplifica com esa,-essa, -ção, -triz, -eza, -ia, -ura, etc, como formadores de feminino e -dor, -mento, -ume, -eiro, -ão, etc., como formadores de masculino.

198 Cf. Maria Carmen de Frias e Gouveia, "Algumas mudanças de género em curso no Português" in Actas do XIII Encontro Nacional da Associação Portuguesa de Linguística (Lisboa, APL, 1998) I, 339-352.

Faculdade de Letras | Universidade de Coimbra 